\author{
Patryk N. Skupniewicz \\ https://doi.org/10.26485/AAL/2021/67/9
}

\title{
NOTES ON THE COMBAT SCENE ON TANG-E SARVAK III ROCK RELIEF
}

\begin{abstract}
The article examines the Parthian rock relief Tang-e Sarvak III from two perspectives: as a source of information on the military equipment, and as representation of the victorious mounted combat genre in ancient Iranian art. As a result of this analysis of the military equipment a picture emerges of a the warrior dressed in a metallic cuirass with central opening, a scale gorget of the old, Achaemenid style, segmented sleeves and lamellar trousers or leggings. His horse is barded in a lamellar caparison, with a longer apron in front which covers mount's chest and partially his legs. The warrior has the archery equipment typical for the late Parthian period, which strongly differs from early Parthian and Sasanian archery equipment. In the course of an analysis of the form of the composition, several possibilities of reconstruction of the missing part of the relief have been proposed. At the same time, the possibility of a large battle scene with a multitude of participants has been excluded as not matching the visual language of the era.
\end{abstract}

Key words: Parthian rock reliefs, Elymaean rock reliefs, Sasanian rock reliefs, Iranian rock reliefs, Parthian arms and armour, Sasanian arms and armour, Composition formulae

\section{UWAGI O SCENIE BITEWNEJ NA RELIEFIE TANG-E SARVAK III}

\begin{abstract}
ABSTRAKT Artykuł dokonuje analizy partyjskiego reliefu skalnego Tang-e Sarvak III z dwóch punktów widzenia: jako źródła bronioznawczego, dostarczającego danych o przedstawionym wyposażeniu bojowym, oraz z perspektywy historyczno-artystycznej, mającej na celu badanie rozwoju motywu zwycięskiego jeźdźca w sztuce starożytnego Iranu. W wyniku dokonanej analizy wyposażenia bojowego tworzy się obraz wojownika odzianego w metalowy kirys otwierany pośrodku tułowia, łuskowy kołnierz starego, jeszcze achemenidzkiego typu oraz folgowe rękawy i lamelkowe spodnie lub nogawice. Jego wierzchowiec oladrowany jest lamelkowym kropierzem z rodzajem lamelkowego fartucha chroniącego pierś konia i jego nogi. Wojownik ma ze sobą późnopartyjski sprzęt łuczniczy który różni się zarówno od wczesno-partyjskiego, ajk i wczesno-sasanidzkiego. W wyniku analizy kompozycyjnej zaproponowano kilka propozycji rekonstrukcji brakującej części reliefu. Jednocześnie wykluczono możliwość wielo-postaciowego, dużego założenia bitewnego, jako nie znajdującego analogii w języku wizualnym epoki.
\end{abstract}

Słowa kluczowe: Partyjskie reliefy skalne, Reliefy skalne Elymaidy, Sasanidzkie reliefy skalne, Irańskie reliefy skalne, Uzbrojenie partyjskie, Uzbrojenie sasanidzkie, Formuły kompozycyjne

Introduction

The Tang-e Sarvak III rock relief is one of the most recognisable depictions of a Late Parthian heavy-armed horseman. ${ }^{1}$ In this way, it constitutes

Bivar 1972; Haernick 2005; Kawami 1987; Kawami 2013; Mathiesen 1992, Michalak 1987; Mielczarek 1993; Mielczarek 1998; Nicolle 1996; Nicolle 2017; Nikonorov 2005; Olbrycht 2010; Skupniewicz 2007; Skupniewicz 2015; Vanden Berghe, Schipmann 1985; von Gall 1990; Wilcox 1986; Woźniak 2010. some sort of icon for research into armoured cavalry in antiquity. Despite its fragmentary state of preservation, surface damage and the missing right section of the composition, the relief is the most accurate representation of the combat equipment, elements of armour and armament of elite cavalry coming from the territory of the Parthian state. The state of preservation of the battle scene in the relief of Gotarzes at Bīsotūn, does not allow any analysis of the armament (apart from the fact that long 
spears were being wielded), ${ }^{2}$ and other monuments depicting armoured horsemen of that period do not come directly from territories under Arsakid rule, while the Parthian art known to us is very scant in its depiction of heavy cavalry. It is therefore not surprising that the relief has been an important source for numerous studies on the Iranian military of the Arsakid and Sasanian periods, as well as in works on Parthian and Elymaid sculpture, during the Arsakid period.

The elements of weaponry depicted on the Tang-e Sarvak III relief constitute an interesting complex, which should be seen as an illustration of a certain stage in the development of Iranian military technology. Precision in rendering details of the elements of the combat equipment being used, meticulous verism, exceeding the technical limitations of the makers of the relief, allow us to consider the representation as being credible from the point of view of the elements of material culture being depicted. At the same time, if we refer these elements to comparative materials in the history of Iranian weaponry against their Eurasian background, it will facilitate their proper identification.

The carved rock-relief plays a dominant role in determining the formation of mounted combat scenes in ancient Iranian art. Taking into account the limited range of compositional solutions available, and the repetitiveness of structural arrangements, as well as the similarity of poses in all depictions of riders defeating their enemies, it is most likely that the Tang-e Sarvak III relief was part of an existing visual tradition. It does not seem possible that, on the one hand, that the relief, the execution of which would require considerable expenditure, and was therefore carved to satisfy the aspirations for self-representation of the highest social strata, could ignore the components of the existing "visual language", and go beyond the limitations of time and place. On the other hand, the part of the composition which is preserved is excellently placed in the developmental sequence of horsed combat scenes, as will be illustrated below. The assumption will be made that the relief stands alone, which will allow us, in turn, to indicate a limited range of possible reconstructions of the damaged relief as a whole.

The goal set for the following text is therefore reconstruction. On the one hand, the reconstruction of the range of weapons being used, and

2 Kawami 1987; Kawami 2013; Luschey 2013; Mathiesen 1992; Mielczarek 1993; Vanden Berghe, Schipmann 1985; von Gall 1990. their place in the history of Iranian weaponry. On the other hand, the reconstruction of the possible compositional schemes being used in the relief, in accordance with the visual formulas applied, completing the section which has not been preserved.

\section{The Relief (Fig. 1)}

The rock relief complex at Tang-e Sarvak (Cypress Valley) is located $50 \mathrm{~km}$ north of Behbahān, in the Baktiāri region of Iran's Khuzestan province. The site comprises a group of rock reliefs dating to the period between the 1 st century $\mathrm{AD}$ and the first quarter of the 3rd century $\mathrm{AD}$. The site is considered to be the largest openair sanctuary from the Parthian period. Considering the accumulation of monumental reliefs, there can be no doubt as to the ceremonial and/or cultic function of the site, but no remains of temple buildings have been found. Since the reliefs were made over a long period of time, and greater distances apart (the first relief is located one and a half kilometres from the other two groups, between which the distance is 40 metres) it seems doubtful that they could represent a kind of common programme, although this can hardly be definitively ruled out, as, after all, the veneration carried out at the sites may have involved a certain processional nature of the cult. However, in view of the fragmentary state of preservation of the individual monuments, making it impossible even to identify the figures unambiguously, the reconstruction of a possible common programme seems to remain beyond the reach of contemporary researchers.

The relief of Tang-e Sarvak III, in its present form, measures $2.20 \mathrm{~m}$ in height, and $2.85 \mathrm{~m}$ in width. The right part of the panel is broken off, leaving a trapezoidal area with the bottom edge longer than the top edge, and the left edge at an almost perpendicular angle to the other sides. The original shape of the format must therefore have been a horizontal rectangle $2.20 \mathrm{~m}$ high and of unknown width, exceeding $2.85 \mathrm{~m}$ in width. ${ }^{3}$

The relief has a strong graphic quality. Despite a certain material depth, the shapes were carved out with sharp cuts without much attention being paid to the gentle construction of the mass. Similarly, the details on the figures were drawn with strong, unambiguous cuts, ignoring subtler methods of

3 Haernick 2005; Kawami 1987; Kawami 2013; Mathiesen 1992, Vanden Berghe, Schipmann 1985; von Gall 1990. 


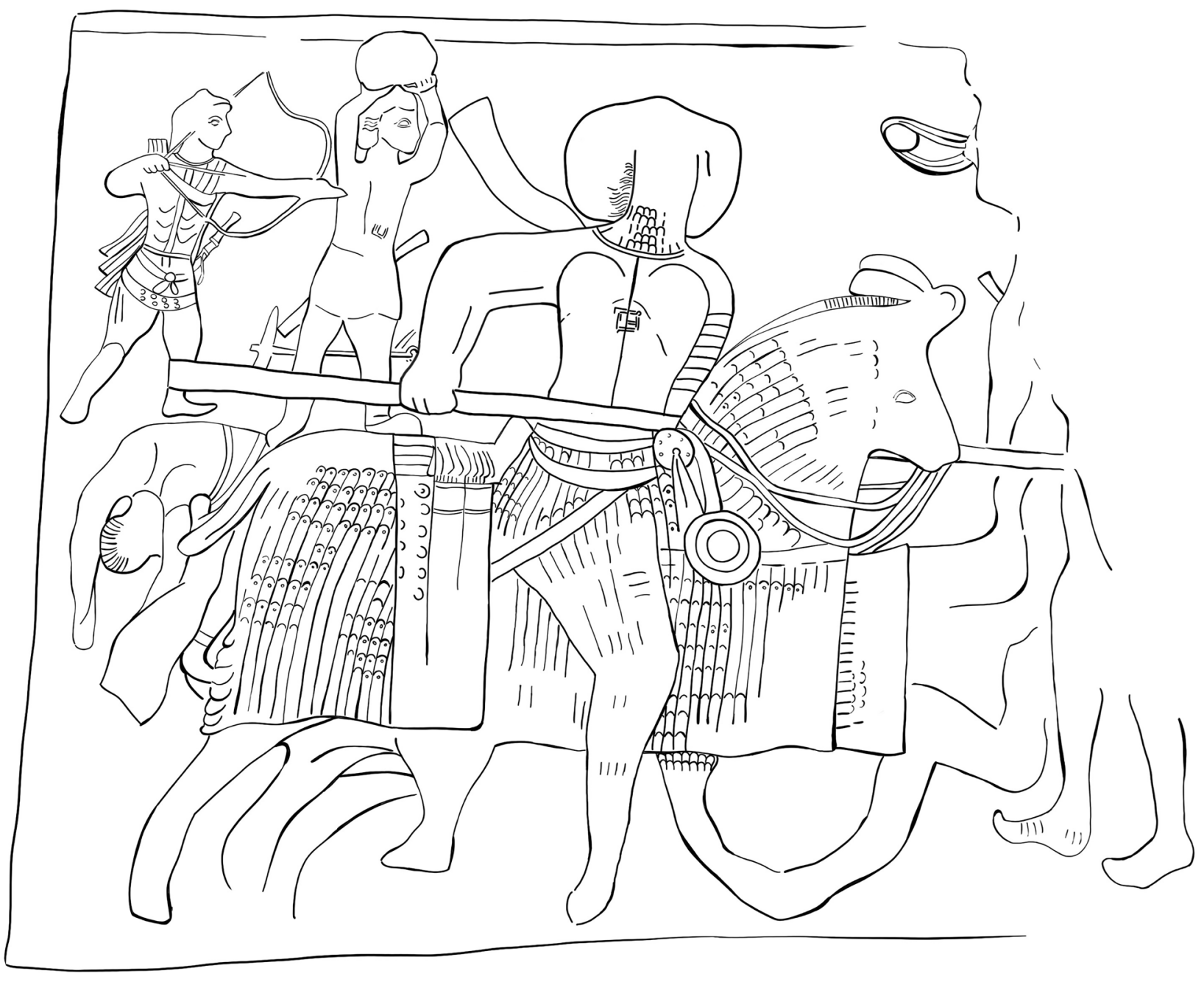

Fig. 1. Drawing of the Tang-e Sarvak III relief (drawn by Eleonora Skupniewicz)

suggesting depth. It could be said that the relief was created as a drawing on two planes, the deeper one forming the background, and the outer one with the sharply cut shapes making up the scene.

In the centre of the pictorial field, is the figure of a heavily-armoured rider, on a galloping horse, also armoured. The figure marks the vertical axis of the relief in its current form, and the long lance he is holding constitutes the horizontal axis. In the upper left-hand "quarter" there are two smaller standing human figures, and a body lying beneath them with helplessly lowered hands. The lower and upper right-hand "quarters" have suffered the most from the breaking off of parts of the block, and the preserved surface is also weathered, making it difficult to make out the shapes being shown. It seems that one can make out a set of bundles or tendrils, which can be subject to various interpretations. One of the strands runs under the horse's belly and touches the rider's leg, the others run vertically, two turn left at their ends, resembling feet. Only the upper right 'quarter' has a horizontal element with a circular filling. The original difficulty in visually identifying the objects on the right-hand side of the representation is illustrated by the differences in the published trace-drawings, which appear to contain an element of interpretation. Similarly, traces of surface damage, caused by erosion, appear to have become indistinguishable from those of the original drawing of the relief. The disagreements in the interpretation of the right part of the relief are so deep that they lead to different reconstructions of the gait of the horse itself. Suffice to mention that the right side of the relief is illegible, which is the result of either erosion, which led to a fragment of the block breaking off, or which followed the break.

The main figure of the relief is shown frontally, from head to waist. The face itself has not survived, but the surrounding hairstyle of thick hair, typical for frontal Parthian representations, makes it clear that the face is shown en face. The warrior is not wearing a helmet. Behind his head there is an arched band pointing upwards. The rider's 
neck is covered by a collar reaching the chin, covered with scales. At the level of the collarbone it is cut off from the rest of the torso by a sharply running line. The torso of the figure is covered by two plates, separated by a vertical line in the middle. Each plate is ends in a semicircle above the chest, and, at the bottom, is clearly separated from the rider's legs by a horizontal edge. At the level of the solar plexus, a small horizontal element can be noticed. The planes appear smooth, any traces of patterns on them may be the result of erosion, although a horizontal zigzag can be seen under the breast, more pronounced on the right side. The rider's right arm is extended backwards, the hand clutching the shaft of the lance, while the left arm is pressed tightly against the torso, the hand not being visible behind the horse's neck. The left shoulder and the visible part of the left arm are covered by a series of transverse lines, invisible on the right shoulder, and, most likely, due to erosion. The rider's legs are covered by armoured leggings, voluminous at the height of the thigh, tapering at the calves. They are covered with a scale pattern with the rounded scales pointing upwards. The rider's feet point downwards, in the 'ballerina's foot' position, popular in Sasanian art.

Behind the warrior's right hip is a bow case, in the shape of an elongated triangle, with elongated arrow shafts.

The horse's torso and neck are covered with a pattern of elongated scales, finishing in semicircles pointing upwards, with carefully rendered holes where the lamellae are tied. The pattern is more worn on the neck. At the base of the neck there is a circular element, most likely a phalera. Despite the pattern of the armour on the neck, a trimmed mane is also visible, and the head of the horse is crowned with a bun and/or decorative ribbons. Elements of a headpiece and reins are visible.

The upper part of the forward-facing legs of the galloping horse is hidden under a rectangular element covered with a similar pattern, pointing horizontally. The lower part of the legs is quite badly damaged, but the shape of the hooves is visible.

The two figures on foot in the upper left section of the relief have their heads shown in profile facing right, while the shoulders and hips are shown frontally. The left-hand figure is shooting from a bow to the right. Behind the body there is a diagonally placed element divided by a series of lines, which may be a kind of cloak or a damaged representation of a quiver. The archer is dressed in a short tunic with a vertical belt, the right side of his torso is covered with a series of diagonal, arching lines. A sword is attached to his belt. The other figure to his right holds a spherical object above his head with both hands. One can guess that he is hurling a boulder. He is similarly dressed in a girdled tunic, although the details are unclear. Behind the figure there is a large battle axe, triangular in form ending in a spike.

\section{Combat equipment}

The Tang-e Sarvak III relief, despite its state of preservation, is a valuable source for the reconstruction of the armament of heavy cavalry at the end of the Late Parthian period. In fact, the closest comparative material are early Sasanian reliefs. Despite the clear effort made by the new dynasty to distinguish itself from its predecessor in the sphere of visual communication, using different stylistic means, power was seized as a result of a civil war, perhaps a struggle between distant branches of the Arsacid family. Therefore, one cannot speak of a decisive change in the military paradigm or a different tradition. The continuity of the military tradition in Iran between the Arsakid and Sasanian periods was decisively demonstrated by Nikonorov. ${ }^{4}$ The equipment of the heavy cavalry on the reliefs of Tang-e Sarvak III, and Firusabad and Naqš-e Rōstām (NRm3, NRm5b and NRm7) must represent the realization of the same concept of equipping the armoured horseman, illustrated over a period of several decades or less than a century. ${ }^{5}$ Naturally, some differences can be discerned, but these cannot account for any revolutionary change associated with the assumption of power by a new dynasty. The differences are due to the evolution of weapon types and changing fashions within the same trend. Naturally, Tang-e Sarvak III should also be associated with other monuments depicting combat between armoured horsemen, but it should be noted that the Sasanian reliefs remain the closest analogy both chronologically and culturally. At the same time, as has already been mentioned above, the Parthian relief of Gotarzes from Bisotun, ${ }^{6}$ dating from the

4 Nikonorov 2005.

5 Bivar 1972; Michalak 1987; Mielczarek 1993; Mielczarek 1998; Nicolle 1996; Nicolle 2017; Nikonorov 2005; Nikonorov 2020; Skupniewicz 2015; von Gall 1990; Wilcox 1986; Woźniak 2010.

6 Kawami 1987; Kawami 2013; Luschey 2013; Mathiesen 1992; Mielczarek 1993; Vanden Berghe, Schipmann 1985; von Gall 1990. 
1 st century $\mathrm{AD}$, undoubtedly also constitutes a close analogy to the relief of Tang-e Sarvak III in its form. Nevertheless, due to its poor state of preservation it does not provide comparative material for the depicted elements of weaponry and armour under discussion here, apart from the fact that the figure also uses a long lance. The Bisotun relief displays affinities with the Tang-e Sarvak relief which cannot be found between Tang-e Sarvak III and Sasanian battle reliefs, but these do not relate to the weaponry depicted and will therefore not be described below. Despite some differences, the Tang-e Sarvak III and the early Sasanian combat reliefs show a fairly consistent picture of the equipment of heavy Iranian cavalry in the third century AD.

\section{II.1. The rider's armour}

The horseman from the Tang-e Sarvak III relief is clad in body armour, consisting of two vertical plates divided by a line in the middle of the torso. The plates are arch-shaped at the top, and finish in a horizontal line. Most probably, therefore, a kind of cuirass protecting the torso is being depicted. The semicircular upper edges of both panels indicate that this cuirass did not extend as far as the shoulders, which must have had an independent type of covering, probably more flexible, permitting the wearer to wield a lance with both hands, or shoot a bow. Kubik interpreted the construction of the warrior's armour depicted on the famous graffiti from Dura Europos in this way, ${ }^{7}$ not dissimilar from the "hybrid armour" concept of Wójcikowski, who was, however, focused more on possible methods of construction rather than functional effects. ${ }^{8}$ The large plates on the graffito would be used to cover the abdomen and the upper part of the chest while the shoulders would be covered with chain mail or small scales, allowing for mobility. The same structural-functional principle was proposed by Negin and Kamisheva in their reconstruction of the armour from the Thracian site of Chatalka (Roshan Drangan). ${ }^{9}$ It seems that this paradigm of armour construction, emphasising the protection of the vital organs of the torso, could be derived from the concept of the Scythian armoured belts, whose segments covered the abdominal cavity, leaving the arms and shoulders unprotected,

\footnotetext{
7 Kubik 2020.

8 Wójcikowski 2013.

9 Negin, Kamisheva 2018; Negin, d'Amato 2018.
}

but also without any restrictions on movement. ${ }^{10}$ As a consequence of the demand for increased protection for the rider, these elements were expanded in their proportions, in line with from experience derived from the battlefield, in which the most vulnerable areas of the body suffered.

It should be noted here that in the Hellenistic period examples of rigid armour constructed from several interconnected, movable elements can be found. Naturally, the best-known form of body protection made of a single sheet of metal in this period was the muscle-cuirass, but this was not the only form of rigid body protection. We may recall here the well-known cuirass from Vergina, which proves that also metal armour was produced in the shape usually associated with linen armour and consisted of several movable parts, connected by hinges ${ }^{11}$. This object somewhat predates the Hellenistic period proper, but culturally it marks its beginning. The horizontal bands from which the great and back plates are made suggest the use of segments attached to each other to create a larger surface area.

Another example of a Hellenistic cuirass comes from the tomb of Lyson and Kallikles, where two such armours are depicted in the southern lunette. ${ }^{12}$ The breastplates are clearly separated from the side- and shoulder-pieces. The structural function of the large rivets on the latter is unclear, but they seem important enough to have been clearly marked.

Armour consisting of several appropriately shaped plates, joined to form a cuirass, is found on a Kushan sculpture from Hadda. ${ }^{13}$ Similarly, the late Gandharan figure of Drvapala from the Metropolitan Museum of Art (1991.132) wears an analogous form of armour, with two large vertical plates, connected by two buckles, covering the abdomen, while on the chest is a covering of scales. It can be assumed that this cover overlaps the higher edges of the abdominal plates. ${ }^{14}$

Perhaps this arrangement, a rigid cuirass with two vertical plates at the front of the body, articulating in the middle, was already developed in the Achaemenid period and was one of the forms of armour used for horsemen in that era. This is demonstrated by an image on a Lydian stele from Manisa, showing a rider with a spear, wearing a helmet and

10 Negin, Kamisheva 2018; Chernenko 1968; Chernenko 1983; Meljukova 1964.

11 Dedjulkin 2021.

12 Sekunda 2012; Sekunda 2013.

13 Gorelik 1982b; Jaeger 2006; Skupniewicz 2007.

14 Behrend 2007. 
cuirass with a clear vertical line in the middle, dividing the torso lengthwise. ${ }^{15}$ Similar vertical lines on the cuirasses of heavily-armed horsemen can be seen on a relief at Firusbad, as well as on one of the graffiti from Dura Europos. ${ }^{16}$ It seems that the marking of a similar element, which is repeated several times on rock reliefs, cannot be accidental, or the result of weathering of the rock, would not make sense if the horsemen were to be depicted in cuirasses made of a single plate, or if they were to wear some kind of textile covering over armour made of smaller pieces. Naturally, the custom of wearing robes or textile coverings over armour by Iranian heavy cavalry is attested in Plutarch's account of the battle of Carrhae, but the same account says that these covers were taken off before the battle, thus they cannot refer to the same function. Ammianus Marcellinus reports that one of the conspicuous features of the heavy Iranian cavalry was the glittering of their armour, which would not be possible if the metal surfaces were covered with cloth. Sogdian iconography depicts warriors in long kaftans worn over their armour in battle, but this is a type of kaftan similar to those worn by men without armour, in contast to possible textile body coverings of early Sasanian warriors, which do not resemble any form of clothing worn at the time.

Possible elements of body protection, sleeveless and reaching to the waist, similar in size to the ones of Firusbad, which can be interpreted as quilted, or combining fabric or felt with metal plates placed between textile layers, can be found in the Kushan iconography of Gandhara, or the painting from Fundukistan. ${ }^{17}$ It should be noted, however, that they only are worn by warriors on foot, with whom the Sasanian rulers certainly would not have wanted to identify themselves. At the same time, these constructions do not have an opening at the front because, with the relatively elastic material of a quilted corselet or kazagand (mail armour placed between the textile layers), they could be pulled over the head, which would positively affect the structural integrity of the armour and therefore its protective qualities. ${ }^{18}$ At this point we recall the story of the duel between Gordafarid and Sōhrāb in the of Šāhnāmē, where the buckles holding the armour together prove to be vulnerable to blows, exposing the warrior to danger. ${ }^{19}$ Even taking into account the considerable chronological distance between Ferdawsi's work and the monuments under discussion, and forming a precise image of what kind of armour exactly the poet had in mind, any conclusions drawn as to what the points connecting the armour the Iranian warriors were aware of, becomes crucial. Naturally, the opening down the centre was of capital importance for arming the warrior, who was thus able to put on and take off his rigid armour by himself or with little assistance, but the additional opening represented an additional element of risk.

It should be noted that Iranian cuirasses with openings at the front, both on the Manisa stele and on the relief at Firusbad, overlap the shoulders, which is different to the Tang-e Sarvak III relief. It is difficult to say whether this difference is due to technical difficulties in making the cuirass, opening from the front, from perfectly fitting plates, which contributed to the short life of this arrangement, or whether it was influenced more influenced by its functionality, requiring the mobility of the arms and shoulders. It must be added that cuirasses with a central opening gained popularity in Central Asia and in the Far East, where they underwent an independent evolution. Korean and Japanese specimens seem to be directly analogous to the relief under discussion. ${ }^{20}$ Opening at the front, they leave ample room for the shoulders and, in some cases, have an independent neck protection, sometimes two plates to provide protection for the throat and the front of the clavicle. Separate chest plates appear to have been added in Central Asia, perhaps of organic or composite materials, as no traces of any such metal elements have survived in Korean or Japanese analogues. Taking into account the appearance of cuirasses composed of several independent fragments as early as the Kushan period, and the example of the late Gandharan Drvapala, it is presumed that the evolution of this type of armour occurred in Central Asia as an attempt to combine an Iranian style of armour with the aesthetics of the Hellenistic muscle-cuirass. ${ }^{21}$ Later on, this solution was combined with segmental and lamellar constructions, but most probably the impulse for their creation came from earlier Iranian armour, evidenced by the depiction of a cuirass from a capital from Bisotun/Ṭāq-e Bostān. ${ }^{22}$

20 Banes 2000; Bryant 1999; Jäger 2006; Skupniewicz 2022.

21 Jäger 2006; Skupniewicz 2007.

22 Skupniewicz 2022. 
The armour shown in the relief of Tang-e Sarvak III, where the plates of the cuirass open lengthwise in the middle of the torso, may be associated with some modern Persian and Indo-Persian armours, included in the chahar-ayna type, although consisting of at least five plates, thus not strictly representing the "four mirrors". ${ }^{23}$ These armours are a kind of plate waistcoat, fastened at the front. Worn over mail, they must have provided excellent protection for the torso. The astonishing similarity may result from similar preferences in fighting technique, although it may be a conscious imitation of the monuments of the past. On the other hand, the resemblance may also have been purely coincidental.

\section{II.2. Gorget}

The neck protection worn by the horseman in the Tang-e Sarvak III relief is a high collar surrounding the neck, covered with scales. Given the evidence of reliefs from Firusabad and Naqš-e Rōstām, warriors tended to wear scale caps attached to helmets. Given the absence of a helmet on the monument in question, logic suggests that we are dealing with a collar, although a stylistic treatment combining an element that would have been worn by a rider with a helmet (as attested in early Sasanian battle reliefs) cannot certainly be ruled out, even though the warrior has been depicted without headgear. It should be remembered that realism was not the main principle governing ancient Iranian iconography.

A collar of metal scales sewn onto a leather backing around the neck was found at Derveni and is thought to be part of the equipment of a Late Achaemenid horseman. ${ }^{24}$ Pieces of armour of this kind are prescribed for cavalry troopers by Xenophon $^{25}$. This element fits perfectly with the depiction in question, but it should also be noted that both armoured collars and gorgets from periods closer to Tang-e Sarvak III relief differ in construction. Similarly, the fragment from Derveni itself finds no parallel in Achaemenid iconography, where armoured cavalrymen tend to have high collars protruding from behind the back of their armour, whether of linen or of a similar construction to the iron armour from Vergina. A gorget, or a high-brimmed pectoral with a raised edge made of a single piece of metal, was also found in

\footnotetext{
23 Skupniewicz 2007.

24 Gorelik 1982; Gorelik 2003; Woźniak 2010.

25 Xenophon, XII, 2.
}

the tomb at Vergina, which may have provided protection for the front of the neck of the armour deposited there. ${ }^{26}$ It could also have been a completely independent element, although illustrating a kind of fashion in neck armour construction. Similarly, by using a pectoral with a raised edge, the issue of neck protection in the armour from Chatalka (Roshan Drangan) was resolved. ${ }^{27}$ At the same time, the protective collars, known from Indo-Sakian, early Kushan monuments, from early Sogdian monuments, and further from the Buddhist art of the area of contemporary Xinjiang province, North China, and accompanying Korean and Japanese armour, form a relatively consistent type, constructed from elongated, vertically fixed lamellae or laminae. ${ }^{28}$ Given the fact that high collars constructed from narrow, vertical, plates are recorded earliest in China, it can be assumed that it was there that this construction developed, and over time was adopted for the kind of armour worn in the steppe and other areas of the Far East. With time, high collars disappeared in favour of mail or lamellar coifs. On this background, the scale collar from the Tang-e Sarvak III relief appears to be a rather archaic and unusual form. One recalls, however, that in the post-Sasanian stucco relief from Chal Tarkhan in the scene of hunting wild boars, the figure spearing an attacking beast with a lance wears an elaborate crown on his head and his neck is protected by a collar covered with a scale pattern. It is difficult to judge whether the hunting customs of the period permitted hunting in elements of armour, or whether the act of fighting dangerous animals was the iconographic equivalent of fighting human enemies, in which case elements of armour would be entirely justified. Similarly, the horseman depicted fighting a lion, pictured on a Parthian plaque from Babylonia now in the collection of the British Museum, is fully armoured, although his armour, which is a kind of scale suit, does not require any special collar or gorget. ${ }^{29}$

It is possible that gorget (av. kuris, pehl. grivpān, n.pers. gribān) had special name. ${ }^{30}$

26 Negin, Kamisheva 2018.

27 Negin, Kamisheva 2018; Negin, d'Amato 2018.

28 Abdullaev 1995a; Abdullaev 1995b; Bryant 1999; Dien 2000a; Gorelik 1987; Gorelik 1993; Ilyasov, Risanov 1997/98; Jäger 2006; Nicolle 1996; Nikonorov 1997; Olbrycht 1999; Pugachenkova 1987; Skupniewicz 2022.

29 Inv. No 91908; Sekunda 1994; Nicolle 1996; Skupniewicz 2016.

30 Malandra 1973; Taffazzoli 1993-1994; Michalak 1987; Khorasani 2010; Wiliam Jackson 1894. 
Admittedly, glossaries define this the word as an element between the helmet and the body armour, so it does not define whether it means a standing collar or a coif, but it is possible that the term occurred pars pro toto as a term for full body armour. Thus, the word may have given rise to the Latin term clibanarii, although this is a hypothetical etymology. ${ }^{31}$ Nevertheless, it is conjectured that both scale armour and neck protection had a specific meaning, the proper identification of which does not seem possible at present.

\section{II.3. Leggings}

The legs of the rider on the relief of Tang-e Sarvak III are covered with a pattern of elongated scales pointing upwards. Almost identical scales cover the torso of the mount. It should be noted, however, that it is not possible for plates shaped in this way to represent scale armour as classically understood, that is, with the plates sewn to a soft backing. The direction in which the ends of the plates are oriented in a semicircle would probably cause them to bend, as the upper row would not hold the lower row, maintaining cohesion. In addition, their length would require several rows of bonding with the substrate, which would have a negative impact on the flexibility of the structure. Therefore, it seems that the most likely structure being depicted is a lamellar construction, where the lamellae are connected to each other in rows that connect independently, which provides considerable mobility while offering good protection. The use of lamellae with semi-circular ends must have resulted from the need for a visual reference to traditional, scale constructions.

One way of protecting the bodies of heavily-armed horsemen was a kind of scale overall, the best-known, but most stylised depiction of which, are the reliefs of Trajan's Column, ${ }^{32}$ which, despite the realistic nature of the stylisation, show horsemen with their skin covered in scales, rather than credible-looking armour. The aforementioned plaque from the British Museum collection, ${ }^{33}$ despite its inferior workmanship, small size and skewed proportions, seems to have a greater degree of realism, which may be due to the fact that the maker actually saw such armour on cavalrymen. Although the scales cover the entire body of the warrior, the areas around the hips and thighs are wider and taper off at the calves. The same arrangement is found on the armoured scale suit on a sculpture in the Nubian Museum in Aswan, where the legs, wide at the hips and thighs, taper only below the knees. ${ }^{34}$ Another example of the depiction of warriors completely covered in scale armour is the decoration of horse harness elements from Yemen, with a probable depiction of an Amazonomachy scene..$^{35}$ These depictions do not indicate the method in which this armour was put on. The openings or bindings are not visible, perhaps specifically hidden behind a scale panel. However, it can be concluded that the area around the hips and thighs, which required greater flexibility when mounting a horse, must also have been wider. It is therefore possible that the opening was in the groin, and the warrior pulled such armour over himself, slipped the legs on, and the inside of the thighs and groin may have remained unprotected, as they were not exposed while riding. The armour from the Scythian barrow 3 Strayki Verkh is an early form of this solution, dating from the 5th century BC, where only the front of the legs is protected. ${ }^{36}$ An analogy could be drawn with the Sarmatian armour from the Vozdvizhensk barrow, which, although made of mail, represents the same method of construction ${ }^{37}$, with the hem of the garment, the length of a foot, probably being tied when riding on horseback. Placing the chain-mail between layers of fabric increased its protective qualities. Such an arrangement would therefore be only partly relevant to the chain-mail shown on the relief of Tang-e Sarvak III, where, although the shape is similar, the way of putting it on must have been different, because the chain-mail does not form a whole with the rest of the armour. It should be noted that the pattern of scales runs to the very lower end of the cuirass, so it is possible that instead of the legs we are dealing with a kind of "armoured trouser", structurally corresponding to the lower part of the scale suit, which could be indicated by a similar distortion of the proportions of the figure.

Scale leggings were a method of leg protection already attested among the Black Sea Scythians. It should be noted, however, that they had to be of a rigid construction, which required leaving gaps
31 Michalak 1987; Mielczarek 1993.

32 Gamber 1964.

33 Inv. No 91908; Sekunda 1994; Nicolle 1996; Skupniewicz 2016.
34 Negin, d'Amato 2018: 15.

35 Antonini 2005; Skupniewicz 2021.

36 Gorelik 2003: 290-291.

37 Kozhukhov 1999; Nefedkin 2011: 141. 
between the joints; the exception seems to be the above-mentioned armour from the 3 Strayki Verkh barrow, which, however, limited the protection to the front part of the leg. Among the cavalrymen of Central Asia of the first centuries AD, a wide leg covering, bell-shaped and extending downwards, but not reaching below the mid-calf, became popular. This solution provided freedom for the rider, but left part of the legs unprotected. Lamellar and scale leggings are attested in Korea and China between the end of the Han dynasty and the Tang dynasty. Such leggings, however, require a type of apron to cover the sensitive area of their suspension. Hence, in early Sasanian rock reliefs or on coins of the Kushanshahs, the upper part of the thighs and groin are covered by scale or mail skirts. $^{38}$

In the case of the Tang-e Sarvak III relief, leg protection is most likely to have been provided by lamellar 'trousers' of a design derived from the scale overalls, the use of which is attested among the Sarmatians in the first centuries AD, and which can be found in Parthian iconography, but were also used in the Roman army. It is possible, however, that leggings and an apron of the same lamellar construction are depicted, covering the vulnerable suspension points of the leggings. An argument in favour of the previous interpretation is, however, the fact that th leg protection widens at the level of the thigh or hip. Wide and long lapels, characteristic of Central Asian heavily-armoured riders, must certainly be excluded.

\section{II.4. Sleeves}

The rider's left arm on the relief under discussion is bisected by a series of transverse lines, which should be interpreted as a depiction of armour constructed from articulating metal hoops, or half-circles. This form of armour for riders had already been mentioned by Xenophon, who called it cheira. ${ }^{39}$ The Athenian author believes that this construction is well-suited for the hand holding the reigns, but it hinders moveability and should not be applied for the right arm, wielding weapons. ${ }^{40}$ Metal sleeves of this type were found at Ai Khanum, and iconography confirms their use in Seleukid armies. ${ }^{41}$ The same, or very similar, armouring of the

\footnotetext{
38 Jäger 2006; Skupniewicz 2007; Gorelik 1982b.

39 Xenophon, On Horsemanship, XII, 5.

40 Xenophon, On Horsemanship, XII, 5.

41 Sekunda 1994.
}

arms can be seen on coins of Indo-Sakan kings, the Khalchayan reliefs, and Kushan coins. ${ }^{42}$ The same design is worn by the warrior on the famous graffito from Dura Europos as well as the Parthian figures on the Firusabad relief and all the figures depicted in the battle scenes on the reliefs at Naqš-e Rōstām (NRm3, NRm5b and NRm7). ${ }^{43}$ Given the requirement for mobility of the arms, it is reasonable to assume that the rings from which the sleeves were constructed could not have been full circles, certainly not along their entire length. Later Sogdian depictions indicate that joints were placed on the inner side of the hoops to ensure adequate mobility to wield lances and shoot the bow. If the "newly-invented piece of armour" mentioned by Xenophon hindered, to some extent ${ }^{44}$, movability, it must be assumed that a significant progress was made in the construction from late Achaemenid to Sasanian times. Examples such as the chariot driver's armour from the tomb of Qin Shi Hunang $\mathrm{Di}^{45}$ and medieval Turkish armour resembling the construction of bekhters, indicate that hoops composed of several segments were able to retain much greater flexibility. Naturally, the hypothesis assuming that full rings covering fragments along the bones and the parts around the joints would consist of movable plates is also acceptable, but the Sogdian examples indicate joints opening for the full length of the arm.

The method of attachment of the sleeves themselves is unknown. As the cuirass does not appear to cover the shoulders, the sleeves could have been hung independently or hung from the flexible armour on the shoulders. Independent fastening of sleeves could be a solution allowing for the better distribution of the weight of the armour, which would be of considerable importance in case of a heavily-armoured rider, who would have to operate a bow and wield a lance and a sword. It must also be borne in mind that similar sleeves were used in the armament of several categories of Roman gladiators, and they were not attached to other armour but independently affixed, however the sleeve described by Xenophon was attached to the cuirass. ${ }^{46}$

42 Skupniewicz. Lichota 2015; Mielczarek 2017.

43 Bivar 1972; Harper 2016; Michalak 1987; Mielczarek 1993; Nicolle 1996; Nicolle 2017; Nikonorov 2005; Nikonorov 2020; Skupniewicz 2015; von Gall 1990; Wilcox 1986; Woźniak 2010.

44 Xenophon, On Horsemanship, XII, 5.

45 Dien 1981; Dien 2000.

46 Xenophon, On Horsemanship, XII, 6. 


\section{II.5. Horse armour}

The mount depicted on the relief Tang-e Sarvak III is fully barded. Its body is covered with rectangular lamellae with a semicircular upper end. In the centre of the circular part there is a small projection, which should be interpreted as a binding element visible on the outside. The armour cuts off clearly at the base of the neck, where a phalera is located, and in front, most of the steed's front, raised legs are covered by a pattern of horizontal lamellae, somewhat resembling the armour covering the rider's body. The horse's neck, on the other hand, is protected by armour consisting of longitudinal elements running along the neck. ${ }^{47}$

The horse armour should therefore be interpreted as consisting, most probably, of three parts: a lamellar caparison, open at the front, protection for the neck, and the lamellar apron placed under the caparison. Horse armour in the form of a caparison is confirmed by two finds from Dura Europos, which, although from the Roman arsenal, are relevant to the tradition of equipping Iranian warriors. ${ }^{48}$ Protective caparisons are attested on the graffito from Dura Europos, on early Sasanian reliefs and are also mentioned in literary sources. ${ }^{49}$ They were also a popular way to protect mounts throughout Eurasia and in modern China. The protective caparison, whether or not covered with an additional layer of scales, was a simple and functional device. Its disadvantage may have been that it left part of the of the horses' legs uncovered, hence the emergence of armoured aprons to protect the chest of the mounts, hanging in front over the legs. The most recognisable representation of this type is the late Sasanian relief at Taq-e Bostan but, a similar design can also be seen on one of the graffiti from Dura Europos. ${ }^{50}$ It seems that the placement of the armoured apron on the horse's chest also protected the sensitive binding area of the caparison. At the same time the breastplate, open in front, limited to a small extent the necessary movement of the apron, as shown in the relief Tang-e Sarvak III, where the series of plates protecting the legs thrown forward during the gallop was depicted horizontally, indicating the flexibility of the arrangement. It should be noted, however, that such an arrangement does not seem to have

47 Skupniewicz 2014; Nicolle 2017.

48 James 2004; Mielczarek 1993; Nicolle 1996; Skupniewicz 2014.

49 Skupniewicz 2014.

50 James 2004; Skupniewicz 2014. been very popular. In the case of the Taq-e Bostan relief, and on the graffiti from Dura Europos it is limited to the front of the mount, the combination of the apron with and the caparison and the depiction of the horse at a gallop can only be found on the relief of Tang-e Sarvak III.

\section{II.6. The lance}

The rider is shown attacking with a lance held at hip level with his right hand, with the shaft across the horse's neck. Most likely the left hand is holding the shaft behind the neck of the mount. Long lances were introduced into the armament of the Iranian cavalry after Alexander's invasion; Darius III was the first to order the lengthening of the lances of his warriors before the Battle of Gaugamela. ${ }^{51}$ During the Parthian period, the long lance became the distinctive armament of the Iranian cavalry as is attested to in the Greek and Latin sources. ${ }^{52}$ In Parthian iconography a lance of this type was depicted for the first time on seals coming from Old $\mathrm{Nysa}^{53}$ and on the relief of Gotarzes, ${ }^{54}$ although it should be noted that it was commonly found in Central Asian iconography. A characteristic feature of the long lance as an iconographic prop in Iranian art is that it is wielded with a lower grip, held at hip level, either along the neck of the horse or across it. There are occasional examples of this weapon being depicted wielded single-handed, but in most cases, the shaft is held with both hands in a manner recalling the use of a rifle with bayonet attached. In Sasanian iconography, lances, which appear to have been shorter, were depicted in scenes of fighting with beasts in blows delivered from above. The example closest chronologically to the Parthian period is the gold clasp from Saksankhur, ${ }^{55}$ however, it can hardly be definitely classified as Arsakid art, but it remains the earliest example of an iconographic type represented several times in Sasanian art.

Due to the distortion of spatial relationships in late Arsacid and Sasanian Iranian art, it is difficult to determine the actual length of the long cavalry lances being used. It is clear, however, that they had considerable reach. A variety of lengths might

51 Olbrycht 2010.

52 Mielczarek 1993; Mielczarek 1998.

53 Gaibov. Košelenko 2008.

54 Kawami 1987; Kawami 2013; Luschey 2013; Mathiesen 1992; Mielczarek 1993; Vanden Berghe, Schipmann 1985; von Gall 1990.

55 Skupniewicz 2009. 
have been employed based on individual preference. Longer shafts would provide an advantage in distance, however they must have been more prone to breaking and required more skill in handling in closing in with the enemy, while shorter lances could be more robust and easier to wield at the cost of distance.

\section{II.7. Gorytos and the bow}

The archery equipment depicted on the Tang-e Sarvak III relief is a late representation of a specific combination of an elongated bow with rigid, bone extensions, elongating the arms and thus increasing the strength of the weapon, the appearance of which should be associated with the expansion of Xiong $\mathrm{Nu},{ }^{56}$ and a large gorytos, i.e. a case for a drawn bow combined with compartments for the arrows. This variety of gorytos, designed for large bows of the Hunnic type, differed from its Scythian ancestor and earlier Persian predecessors by its size and also by two integrated arrow tubes and a different way of carrying it; on the right hip. A certain period of time can be observed between the expansion of the tribe itself, and the widespread adoption of this new type of bow throughout Eurasia, which testifies to a kind of conservatism of warriors and the fighting techniques they used. It is therefore important to note the conventionality of the term. Although, the first bows with rigid ear extensions are associated with the Xiong $\mathrm{Nu}$, the identification of this ethnos with the later Huns is not clear. Whatever the reason, the revolution that constituted the adoption of the 'Hunnic' type of bow is noticeable in Western Eurasia at the turn of the eras, and even more more in the first-second century AD. ${ }^{57}$

A gorytos adapted to the Hunnic-type bow was found at the Niya site in Xinjiang ${ }^{58}$. Further examples can also be found on depictions on plaques from Orlat ${ }^{59}$ on plaques from a Takht-e Sangin, ${ }^{60}$ where they are shown together with bows of the "Hunnic" type in use. Large gorytoi

\footnotetext{
56 Nikonorov, Hudyakov 2004: 45-69; Vinogradov, Goroncharovskij 2009: 189-193.

57 Mielczarek 1999: 44; Vinogradov, Goronczarovskij 2009: 190.

58 Iljasov 2013: 100.

59 Pougachenkova 1987; Brentjes 1990; Abdullaev 1995a; 1995b; Nikonorov 1997: 17, 75, fig. 43a-c; Ilyasov, Rusanov 1997-98; Nikonorov, Hudyakov 1999; Olbrycht 1999: 204-206.

${ }^{60}$ Nikonorov 1997: 11, 59, Fig. 27; Litvinskij 2002.
}

with side sleeves for arrows are depicted on gold clasps from the Siberian Collection of Peter I. ${ }^{61}$ The presence of "Hunnic" type bows, corresponding gorytoi and long-bladed swords in scabbards with the scabbard slides argues against the frequently found dating of these objects to the fourth to the second century $\mathrm{BC}$ and brings them closer to the aforementioned objects from Orlat ${ }^{62}$ and Takht-e Sangin and the plaque from Kalala-Gyr $2 .^{63}$ In the Black Sea region, the first century AD is the transitional period when the new "Hunnic" gorytos appear alongside the gorytos of the older, "Scythian" type ${ }^{64}$. This means that the adaptation of the new form of weaponry was not immediate and explains the long time between the appearance of the heavy Xiong Nu bows and their adoption by the rest of Eurasia. Bosporan monuments, such as the epitaph of Stratonik, son of Zeno, and Matian, son of Zaidar, indicate that the practice of carrying unstrung bows was widespread. Similarly, as mentioned above, the 'Scythian' bow, with the gorytos carried on the left hip, was in use in Parthia until at least the second century AD. It may be that the length of time that the bow was strung had a more detrimental effect on the long 'Hunnic' bows than the earlier 'Scythian' bows.

Parthian art also shows a change in the type of bow in use, as evidenced by reliefs from Elymais, such as theTang-e Sarvak III relief under discussion ${ }^{65}$, a terracotta relief from the British Museum, ${ }^{66}$ where the practice of placing a dagger, or short sword, on the surface of the gorytos, between the tubes for holding arrows, is illustrated. An identical representation, comprising a case for a drawn bow and two tubes for holding arrows, worn on the right side is also shown in a relief from Rag-e Bibi, an object which is often identified as Sasanian, which is, however, also found in late Kushan representations. ${ }^{67}$ Great caution should be

61 Simpson, Pankova 2017: 57 - Nr inw. Si 1727 1/162, 64 - Nr inw. Si 1727 1/70.

62 Pougachenkova 1987; Brentjes 1990; Abdullaev 1995a; 1995b; Nikonorov 1997: 17, 75, fig. 43a-c; Ilyasov, Rusanov 1997-98; Nikonorov, Hudyakov 1999; Olbrycht 1999: 204-206.

63 Iljasov 2013.

64 Mielczarek 1999: PL. XVII; Nefedkin 2011: 139; Vinogradov, Goronczarovskij 2009: 159, 162, 191; Goronczarovskij 2003: 30, 34, 74.

65 Kawami 1987: 201-204; 2013: 760; von Gall 1990: 13-19; Mathiesen 1992: 130-132; Haerinck 2005.

$66 \mathrm{Nr}$ inw. 135684; Herrmann 1989.

67 Grenet 2008; Maksymiuk, Skupniewicz, Kubik 2020. 
exercised in the case of arbitrarily expressed opinions, devoid of iconographic analysis, which raises doubts about a similar attribution, contrary to both reality and aesthetic principles.

The large gorytoi with Hunnic bows must have been quite a nuisance either when mounting or walking on foot. They are depicted almost exclusively being worn by mounted figures. At the same time, one of the dismounted warriors in the battle scene from the Orlat plaque has a gorytos attached to his belt. ${ }^{68}$ Having a gorytos at his belt, even after losing his mount, the warrior could carry on shooting. It is therefore difficult to say whether the custom of suspending bow cases onto saddles actually existed, or whether it depended on local or personal preferences. It seems, however, that there are more arguments in favour of the fact that the large gorytos for "Hunnic" bows with arrow tubes were worn at the waist, on the right side. They represented a modified tradition of mounted archery dating back to the Median expansion.

An interesting source illustrating the transition period between the 'Scythian' and 'Hunnic' bows is the stele of Athenaios from Kerch, where the deceased is shown on horseback in two panels, in one, facing left, he has a 'Scythian' bow at his left hip, and in the panel below, facing right, he is shown with a 'Hunnic' type bow with two tubes for holdings. ${ }^{69}$

A model preserved in a burial from Oglakhta from the Tarim Basin can serve as an example of a gorytos of this type. It has a stick imitating a bow and miniature arrows in a separate case, and is now in the Hermitage collection. ${ }^{70}$ The artefact is dated to the late third or early fourth century $A D$, which may indicate a kind of conservatism in local military technology, or to the prolonged use of the object prior to its burial. Tashtik art appears to show 'Scythian' bows despite dating to the second or third century AD..$^{71}$ This may be due to the simplified stylization of the images but might illustrate that the shorter bows had actual advantages in particular environments.

During the Sasanian period, the bow did not lose its symbolic function associated with power. Among the numerous equestrian depictions, the

68 Pougachenkova 1987; Brentjes 1990; Abdullaev 1995a; 1995b; Nikonorov 1997: 17, 75, fig. 43a-c; Ilyasov, Rusanov 1997-98; Nikonorov, Hudyakov 1999; Olbrycht 1999: 204-206.

69 Brentjes 1995-96: 184, 193; Vinogradov, Goronczarovskij 2009: 189-191, il.92.

70 Nr inw. 2864/21; Simpson, Pankova 2017: 351.

71 Pankova 2011. king has a quiver with him. This is a rule from which occasional exceptions appear. The bulky, tubular and long Sasanian quiver, with no space for a bow, seems to have gained in importance. It is possible that by avoiding depictions of integrated bow and arrow cases, the Sasanians intended to visually dissociate themselves from the previous dynasty. Of course, on the relief at Firuzbad, both sides have the characteristic large quivers of the Sasanian type, which may mean that they appeared much earlier and by the third decade of the third century AD, had definitely fallen out of use in Iran. It may also be that such quivers were a status designator, by which Firuzbad indicates that the battle is between equal opponents.

The move away from the integrated bow and arrow case seems to have been gradual, and although the lack of references to such an arrangement is a prominent feature of Sasanian iconography, the abandonment of the bow case was more evolutionary and predated the appearance of the Sasanians. Iconographic material is provided by Palmyrean art, where single tube-shaped quivers appear alongside gorytoi with one or two tubes for arrows, with no provision for cases for stringed bows. The so-called Odaenathus mosaic shows a double tube for arrows, but no integrated bow case. ${ }^{72}$ If the dating of the monument is correct, it would date from the reign of Shapur II, that is, a long time after the fall of the Arsakid dynasty, when the large gorytos with space for a bow and two tubes for arrows ceased to appear in Iranian iconography. Similarly, in the case of the wall paintings of the synagogue from Dura Europos, unanimously considered to refer to Parthian iconography, as well as the graffiti, depict long, tubular quivers rather than integrated gorytoi. On the graffiti with the Iaribhol cult scene or the lion hunt ${ }^{73}$, the tube is divided into two parts, perhaps the representation should be understood as two connected tubes, analogous to the "Odaenathus mosaic". It should also be noted that the iconography of the iconic Iarhibol scene from Dura Europos includes pompons or tassels hanging from the saddle, which is an element characteristic of Sasanian imagery. ${ }^{74}$ Single quivers of tubular shape are depicted on paintings from the Mithraeum at Dura Europos ${ }^{75}$ and the graffiti with scenes of the chase after fleeing game from Hatra. It seems that the quivers depicted in Dura Europos

\footnotetext{
72 Gawlikowski 2005.

73 Rostovstev 1934: PL XXV, XXVI.

74 James 2006.

75 Driver 2016.
} 
and Palmyra represent a type known from the depictions of Syrian archers from Trajan's column, which would be worn on the back when fighting from foot, but strapped to the belt, or hung so as to hang at the hip or thigh when riding on horseback, while the graffiti from Hatra depict quite mature, 'Sasanian' archery equipment. ${ }^{76}$ Whatever the direct inspiration or the reason for the abandonment of gorytos in favour of separate quivers, the process was begun in the late Sasanian period, as the graffiti from Dura Europos suggest that double arrow tubes were still in use even after their combination with the bow-case had ceased.

Tang-e Sarvak III thus represents the latest example of the depiction in Iranian monumental art of a large bow with overlapping gorytos worn on the right hip. It is therefore evidence of a change in custom or technology. The reliefs from Firusabad created shortly afterwards with a similar theme, and other early Sasanian reliefs, clearly break away from this tradition. One can therefore conjecture that this is the result of a deliberate iconographic procedure, aimed at dissociating oneself from the visual formulas of the previous dynasty. Naturally, such a procedure could not have existed in a vacuum and the preference for long, cylindrical quivers must have existed beforehand, but it is difficult to believe that in a traditional army of experienced warriors, the Sasanians could, in a short period of time, force a 'modernisation of equipment'. It seems that the process must have been evolutionary and the presentation of new rulers with quivers only accelerated their spread. However, it is notable that Sasanian iconography meticulously presents kings with quivers rather than combined bow and arrow cases.

\section{Composition}

The Tang-e Sarvak III relief, although not fully preserved, is an important example of the development of scenes of victorious horse combat in ancient art. Every attempt to reconstruct, even roughly, the layout of the relief, must take into account the sequence of traditions in which it participates. Not only scenes of fighting between humans should provide comparative materials, but also representations of heroic encounters, which, although stemming from the Near Eastern tradition, took over the elements of depicting scenes of violence involving horsemen, whose original sources can

\footnotetext{
76 Riccardi 1998; Kubik 2020.
}

be found in Assyrian art, but in Achaemenid and Greek art were transformed into kinds of "icons of violence", ${ }^{77}$ including fixed elements, which, significantly influence the principles of composition. It seems that illustrating violence, or rather victory through violence, took similar forms regardless of whether the defeated was a man or a beast.

Since the relief depicts a single, dominant horseman and the other preserved figures are on a much smaller scale, we should reject the possibility that a multiform composition combining several scenes was depicted, forcing one to use one of the procedures aimed at their harmonious combination in one work. The shape of the block of rock indicates that the broken off fragment could not have been large enough to allow a second scene of the fight (if we were talking about models defined as "medallions", "twin scene"), or even the a rider attacking the main figure from the other side (as would be possible in the case of a composition showing "the victim in the middle of the composition"). ${ }^{78}$ Both options would require the assumption that the preserved fragment constitutes not a full half, or a one third of the whole scene set in the format of an elongated, horizontal rectangle. Such compositions are characteristic of Hellenistic art, whose legacy existed in Iran, but it is difficult to assess the extent of their popularity. The existence of multipersonal battle scenes is confirmed by the Gotarzes relief, the wall painting from Dura Europos, and the reliefs from Firusbad. ${ }^{79}$ In all cases we are talking about a composition repeating individual scenes, included in a compact format inscribed in a circle or square/short rectangle. The repeated rhythm of scenes corresponds to the model of "medallions", however, in the case of Tang-e Sarvak III, we are certainly dealing with an independent scene.

Among the known compositional patterns of depicting battle scenes used in Hellenistic and post-Hellenistic art, any analysis of the composition of the Tang-e Sarvak III relief should exclude patterns where (1) the horseman strikes the infantryman standing behind him, that is, in the direction opposite to the direction of the gallop, as the attack is frontal (2) the confrontation of two horsemen, as the size of the lost part would not allow it and (3) the horseman strikes vertically downwards,

7 Skupniewicz 2018a; Skupniewicz 2018b; briefly on continuity of schemes of depicting violence in Iranian art, see: Harper 2006.

78 Skupniewicz 2018a; Skupniewicz 2018b.

79 von Gall 1990; von Gall 2008; Skupniewicz 2015; Skupniewicz 2016. 
again, clearly to be rejected as the victorious rider is holding his weapon directed horizontally. ${ }^{80}$

It is therefore necessary to relate the composition of the Tang-e Sarvak III relief to one of the following formulas:

\section{III.1. A rider confronting a standing opponent on foot}

It should be noted, however, that Tang-e Sarvak III does not use a variant of this model which includes a figure stretched under the hooves of the victorious rider, a variant which became dominant in the Sasanian period, and which can be found in numerous examples of the toreutics of the period, ${ }^{81}$ but also the reliefs from Naqš-e Rōstām seem to refer to this model, although their format was modified to a rectangle stretched in the horizontal plane. This model, enriched with a victim stretched at the bottom of the representation should therefore be treated, in relation to the monument currently under discussion, as a variant of the arrangement of "horseman confronted with a standing opponent". ${ }^{82}$ In this formula, the victor is usually shown galloping to the right, occupying most of the field, while his opponent is a vertical accent closing the format, "absorbing" the energy of the rider's attack. In most cases, in order to subordinate the composition to the principle of isokephalia, the infantryman is shown as disproportionately larger than the rider. A frequent prop found in this formula is a large shield, most often an oval thyreos. This treatment emphasises the vertical character of the figure, accentuating the restriction of the dynamic movement of the rider. Examples of this group include representations from Anatolian Greco-Persian seals,${ }^{83}$ a wall painting from the Kinch Tomb ${ }^{84}$ paintings from a Thracian tomb at Alexandrovo ${ }^{85}$ or a Scythian gold plaque from a barrow at Geramesovo ${ }^{86}$ and

80 Skupniewicz 2015; Skupniewicz 2018a; Skupniewicz 2018b.

81 Harper 2006; Skupniewicz 2015.

82 Skupniewicz 2018a; Skupniewicz 2018b.

83 Boardman 1970: 303-357; Ma 2008: 243-254; Vassileva 2010: 37-46; |Skupniewicz 2018a; Skupniewicz 2018b.

${ }^{84}$ Chaniotis, 2005: 196, il. 10.1; Markle 198: 90; Skupniewicz 2018a; Skupniewicz 2018b.

85 Vassileva 2010: 39-44; Skupniewicz 2018a; Skupniewicz 2018b.

86 Gorelik 1971; Skupniewicz 2018a; Skupniewicz $2018 b$. several Etruscan urns. ${ }^{87}$ In later art, the confrontation of a lance-wielding cavalryman with a shield-protected, standing infantryman is attested in the Parthian seals from Old Nysa, ${ }^{88}$ and in the early Kushan gem from the Jonathan Rosen collection cited by Gaibov and Košelenko, ${ }^{89}$ and also on several examples of Sasanian toreutics. ${ }^{90}$ Looking for the origin of this formula one can recall the decoration of a golden scabbard of an $a k$ inakes from the Oxus treasure, ${ }^{91}$ where the body of the scabbard was decorated with a pattern of riders shooting from their bows at lions standing on their hind legs. The decoration on a clay plaque from Babylonia, dating to the Parthian or Late Seleucid period, now in the British Museum, showing a confrontation between a heavily-armed horseman and a lion shown as a protome emerging from outside the picture frame. ${ }^{92}$

A popular development of the above formula was the addition of the outstretched body of a defeated enemy under the horse's feet. It is possible, however, that the formula described above was a rather reduced version of the one including the victim stretched below, although it should also be noted that the body of the slain opponent is one of the "props" appearing in formulas of combat on foot, or accompanying other representations of mounted combat. Although the relationship between the two compositional formulae is clear, it is impossible to determine which one was the original one. It cannot be stated with all certainty if the confrontation without the lying figure is reduction of the formula including it or vice versa. Figures trampled over by chariot horses were an important element in Egyptian and Assyrian iconography. It is noteworthy that the victim horizontally stretched out, together with the vertical element, which is the opponent attacked by the main character, delimit the scene from below and from the right (only occasionally the attack comes from the right). The horizontal element under the mount's hooves on the one hand defines the ground-level, and on the other

87 Pirson 2014: 252-274; Skupniewicz 2018a; Skupniewicz 2018b.

88 Gaibov, Košelenko 2008: 99-107; Pilipko 2001: 322; Skupniewicz 2009: 49-65; Skupniewicz 2015: $235-$ 265; Skupniewicz 2015: 180-211; Skupniewicz 2016; Skupniewicz 2018a; Skupniewicz 2018 b.

89 Gaibov, Košelenko 2013.

90 Skupniewicz 2016; Harper 2006.

91 Stornach, 1998: 231-248; Boardman 2006: 115 -

119; Skupniewicz 2018a; Skupniewicz 2018b.

92 Nicolle 1996; Sekunda 1994; Skupniewicz 2009: 49-65; Skupniewicz 2015: 235-265; Skupniewicz 2016. 
emphasises the direction of the attack, adding dynamism to the impression of a collision with a vertical opponent. Significantly, this formula seems to have a decidedly Middle Eastern origin and survived the longest in the Middle East. The two oldest examples are a bronze plate of Asurbanipal II now in the collection of the British Museum, and the seal of Cyrus (grandfather of Cyrus the Great) of Anshan. ${ }^{93}$ Later we find the formula in the reliefs of the southern frieze of the temple of Athena-Nike from the Parthenon (now in the British Museum), several Athenian tomb reliefs, Anatolian art in the late Athenian period, on Greco-Persian seals, the Payava sarcophagus. ${ }^{94}$ Later on several Bithynian stelae, on the Aemilius Paulus monument from Delphi, or on silver decorations of a horse harness from Letnica in Thrace, where it was used to depict a scene of a fight with a bear. The victim is stretched horizontally under the hooves of the horse of the victorious rider, attacking the beast stretched vertically and closing the format is the basic formula for the so-called hunting scenes in Sasanian and post-Sasanian toreutics, where it further developed on several minor formulas. The fight of the horseman with tigers on the Palmyrene mosaic discovered by Gawlikowski was depicted in a similar way. ${ }^{95} \mathrm{He}$ points out that in later periods this formula was mainly used to show scenes of fighting with beasts, strong animals threatening the hunter's life. An exception is the Lombard or Byzantine patera from Isola Rizza, where an armoured rider is shown galloping to the right, over the stretched body of a fallen enemy. ${ }^{96}$ The hero attacks a standing opponent with a kontos, who unsuccessfully tries to protect himself with a shield. In the Author's opinion, this is the, faithful, example of use of the formula under discussion to show fighting between people. The rock relief from Taq-e Bostan which depicts a victorious rider opposed by an opponent on foot to the left, with two bodies stretched below, is following the same compositional scheme, however the attack is directed obliquely downwards thus being a combination of earlier composition principles. ${ }^{97}$

93 Harper 2006: 14-18, 46, fig. 16; Skupniewicz 2018a; Skupniewicz 2018b.

94 Pirson 2014:230, tabl. 34; Ma 2008: 244, fig. 3; Nefedkin, 2006: 8, fig. 3; Boardman 2006: 303-357; Skupniewicz 2018a; Skupniewicz 2018b.

95 Gawlikowski 2005. s. 1293-1304; Harper 2006.

P. Skupniewicz, 2015, 180-211.

96 Skupniewicz, 2015, s. 235-265.

97 Moradi, Compareti 2019.

\section{III.2. The victim shown obliquely}

The formula of the rider's domination over an infantryman or a predatory animal, which gained the greatest popularity in ancient art and was eagerly copied in modern times, depicted a rider on a rearing or galloping horse, when the front hooves are raised and hind standing firmly on the ground, which in itself emphasised the diagonal direction of the composition, but was reinforced by the diagonal representation of the crushed victim, whether helplessly resisting the rider, desperately seeking escape or falling down after the rider's blow. The direction of the attack is exactly or close to perpendicular to the line Examples of the use of this model are abundant, among them are again Athenian epitaphs, the Achaemenid-*Trotskyite patera with a depiction of a bear hunt and the related tumulus plaque from Pechova, in a battle scene from the Greco-Persian, Anatolian sarcophagus from Čan, ${ }^{98}$ and further this formula became established in Hellenistic, Etruscan and Roman art of the principate period, its examples can also be found in Sasanian silver platters. ${ }^{99}$ Again, the genesis of the formula in question can be sought in Assyrian art, exemplified by fragments of reliefs by Tiglah Pilaser, now in the British Museum. The direction of the attack diagonal downwards is also visible on the decoration of the neck and the pendant of the akinakes scabbard from the Oxus treasure. ${ }^{100}$ Interestingly, due to the heraldic placement of hunters attacking a lion rearing on its hind legs, the monument represents both the type in which the victim is turned towards the pursuer, responding with a fight to his overwhelming attack, and turning away from him, as if trying to escape. It is possible that models of galloping horsemen trampling victims standing on the ground in a clearly oblique direction in Indian art are derivatives of this formula, even if they are reserved for architectural cantilevers that make structural use of their oblique position but do not enter any pictorial field. A related formula seems to be the representation of a rider on a mount standing oak or at a gallop being attacked obliquely by a boar, as can be seen in the hunting scene from the sarcophagus from Čan mentioned above, the stele from Yaničköy,

98 Sevinč, Korpe, Tombul, Rose, Strahan, Kiesewetter, Wallrodt, 2001; Ma 2008: 243-254; Woźniak 2010; Skupniewicz 2018a; Skupniewicz 2018b.

99 Skupniewicz 2015; Skupniewicz 2018a; Skupniewicz 2018b.

100 Stornach, 1998: 231-248; Boardman 2006: 115-119. 
later present in Sasanian toreutics and stuccowork, where the horse is also sometimes shown standing and, apart from boars, the repertoire of beasts was extended to include representations of lions. ${ }^{101}$ Taking into account the direction of the rider's attack, oblique and downwards, usually towards the right, and the opposite, weaker attack of the victim, a combination of both aspects can be seen in Etruscan urns, where the defeated figure thrusts a sword into the breast of the victor's steed. At the same time, attention is drawn to the fact that originally the diagonal direction of the defeated figure, marginalised towards the lower right corner of the format, was occasionally combined with the first of the formulas discussed, i.e. 'the horseman confronts a standing, on-foot opponent', This was done by closing the image field with a vertical element, either by significantly enlarging the size of the victim's figure, or by showing him in an oval shield held upwards, or additional vertical figures (on Etruscan urns), or a tree (the sarcophagus from Čan, the stele from Yaničköy, Etruscan urns).

On the decoration of the crest from the Solokha barrow, the classical square composition was modified and the main figure of the warrior, who was defeated, was depicted attacking his pursuer diagonally upwards, which resulted in a composition in the shape of a flat triangle. ${ }^{102}$ Undoubtedly, however, the comb from Solokha retains the constant elements of the discussed schemes in a specific development. Sometimes, under the horse of the rider attacking the victim, whose position draws a diagonal line parallel to the main diagonal direction, the stretched body of the dead victim is also shown, which indicates that the mentioned formulas were not treated rigidly and were allowed to interweave, creating new qualities.

\section{III.3. Assistance to the main figure}

The pedestrian helper of the heroic rider is a recurring element in numerous representations. Depicted as a lightly-armed prodromos in Hellenistic art, in accordance with Greek riding tactics, over time the foot figure behind the rider became a recurring frequent element in depictions of the victorious horseman. In Hellenistic and Roman art the assistant to the main hero was

101 Ma 2008: 243-254; Vassileva 2010: 37-46; Skupniewicz 2015: 180-211; Skupniewicz 2018a; Skupniewicz 2018b.

102 Skupniewicz 2018a; Skupniewicz 2018b. shown as a half-figure visible from behind the horse or as a full figure placed behind the rider. In Iranian art the figure of the helper or helpers began to be shown as reduced figures placed above the rump of the horse and in the reliefs of Naqš-e Rōstām this figure was rationalised to an "ensign" carrying the banner of the victorious king. In the Rag-e Bibi relief, considered to be Sasanian or late Kushan, the main figure is accompanied by two horsemen depicted on a smaller scale. In the Tang-e Sarvak relief under discussion, the figure of an archer accompanying the main horseman appears, and a continuation of this tradition can be found in the lower part of the plaquette with depictions of battle scenes from Orlat. One can speculate that a symmetrical figure of an archer might have closed the composition, directing the viewer's attention towards the centre. The weapon which appears in the hands of the auxiliaries of the main rider, or accompanies them, lying at their feet is an axe. In a fragmentary relief from Yemen, a reduced figure of a walking attendant is armed with an axe and a buckler. This element seems to derive from the scenes described above as 'prey in the centre', where most often the naked figure with the axe is treated as one of the hunters flanking the animal, or appears between one of the hunters and the fighting beast. The origins of this motif are to be found in Neo-Hittite iconography (reliefs from Sakčagöz, Kargamiš), although the way in which it would have been transferred to the ensemble of Early Hellenistic imagery, from where it spread to Thrace, Etruria, Iran and Central Asia, is unknown.

\section{III.4. The position of the victim}

According to the principles of clear communication, the defeated figure had to be shown in an unambiguous manner. One of the positions of the dying victim is to show him kneeling on a bent left leg with the right leg straight. This is a method commonly used, known from the sarcophagus of Čan, Bithynian stelae but also Etruscan urns. This position is used to depict Decebal committing suicide on Trajan's column, but one can also see a reference to this position in the battle scene on the plaque from Orlat. In the western Mediterranean the defeated enemy was shown curled up, on all fours, which is sometimes interpreted as a reference to sexual violence. In the representations "confronting" the rider with the infantryman, the latter is often shown standing upright, facing the hero dynamically, his vertical position is often emphasised by an oval shield, the thyreos, and the 
head of the infantryman, according to the principle of isokephalia, is placed at the same level as the rider. This model may correspond with Sasanian representations, where the victorious rider is contrasted with the still upright enemy. Basically, therefore, the position of the victim is matched to the visual formula used, although sometimes, as in the case of the stele from Kadyand, we have the victim in a kneeling position on the left leg with the right leg extended, but with a rigidly upright body and a large shield.

In the case of the Sasanian reliefs, what draws our attention is the contrast between the steady, stable position of the victorious riders, demonstrating composure, and the violent dynamic depictions of dying enemies and their mounts. The position of the dying enemy, full of helplessness against the force of the lance's blow, in the case of the central figure in the relief from Firusabad, and the three duellists from Naqš-e Rōstām still captures them with their heads up, bent under the power of the blow, but still with their heads upright. Meanwhile, the opponent in the right-hand scene in Firusabad and Naqš-e Rōstām is depicted on a mount bucking after a blow, head down.

It should be noted that the armoured horseman, in the iconography that is known to us, may be shown in victorious combat with an opponent on foot, whether unarmoured or armoured, or an unarmoured or armoured cavalryman, but the figure of an unarmoured victorious horseman is never shown defeating an armoured opponent. ${ }^{103}$ The lightly-armoured horseman can therefore only defeat lightly-armoured opponents, whether on horseback or on foot. This rule seems to be linked to the function of armour, a costly item, as a status marker. That the victor could be a hero struggling without protection for the body was not allowed, as it would suggest that he could be poorer, poorer than the defeated opponent.

\section{III.5. The dead, dying and escaping horse}

The slaughtered mount, most often with visible projectiles protruding from their bodies, appears in three contexts: (1) as a dead horse with the defeated figure still sitting on it, most often shown in a position with the knee bent and the other leg straightened; it seems that it was from this model that the ways of showing combat between

103 Skupniewicz 2018a; Skupniewicz 2018b; Skupniewicz, Lichota 2017. mounted figures in Sasanian reliefs developed. Most probably this model was used in the eroded relief of Gotarzes, which in turn depended on Hellenistic sources, as is attested by the left side of the Alexander Mosaic and the right scene of the long side of the Alexander's sarcophagus. Similarly, a partially preserved wall painting from Old Nysa shows a warrior with an arrow in his eye, Similarly, a partially preserved wall painting from Old Nysa shows a warrior with an arrow in his eye, riding a wounded horse. Although the incompletely preserved monument does not allow us to state with certainty that it uses one of the above-mentioned compositional formulas, we can presume that if the "props" were used in accordance with the above-mentioned premises, the composition should represent one of the models. The vividness of the motif is confirmed by the image from the plaque from Orlat, but also the representation from the silver cup from Kosika may refer to the model being discussed in an indirect way. It is true that the wounded horse gallops, dragging the inert body of the defeated warrior, but the arrow stuck in it is carefully marked. It can be presumed that the scene from the monument from Kosika was influenced both by the models of the triumph of the heroic rider and the pursuit of the fleeing enemy. (2) The mount brought down together with the defeated rider, rolling after the blow, examples of this model are the reliefs from Firusabad (the middle and right scene) and Naqš-e Rōstām. The position of the animal is repeated almost identically, with one hind leg thrown up and the other bent under the belly, and similarly one front leg stretched forward, the other sharply bent towards the body. The head is only visible in relief from Naqš-e Rōstām, but, given that the same formula was used in hunting scenes in toreutic, it must be considered a quasi-canonical depiction. It is significant in the case of mounted combat scenes, that one of the hind hooves of the falling horse is shown pointing upwards, at the level of the attacking warrior's head. (3) A horse standing on its hind hooves under the force of a frontal blow, a formula present in the Naqš-e Rōstām reliefs. It is difficult to determine whether the horse was intended to be depicted as hit and dying, or merely thrown backwards as a result of the force of the victor's blow striking the enemy cavalryman. (4) The fleeing horse without the rider must have been an important prop or even compositional determinant as it is represented on the scene from the vessel from Orlat, but also on the relief of Gotarzes, one of the panels of Aemilius Paulus monument in Delphi, and is preserved in one of the fragments 
of the battle scene from Khalchayan. The riderless horses cannot represent the spare mounts as this would not fit the heroic content of the representation. They clearly mark that the rider opposing the victorious warrior was already unhorsed and defeated. In Iranian culture this might have been important element which excused application of the formula known for confrontation of the rider with an infantryman. Depiction of the fleeing horse explained to the viewer that the clash has taken place between the equals and the fact that the defeated personage is shown dismounted does not imply his infantryman status which was considered far lower than cavalry.

\section{III.6. The arrow in the eye of the victim}

The motif of a victim hit in the eye with an arrow or javelin appears in numerous representations. Examples of this are the stele from Kandyada, a wall painting from Old Nysa, or in the fragmentary plaque from Orlat. ${ }^{104}$ Perhaps blinding before death was a kind of artistic or aesthetic topos of Indo-European character. In the scenes of killing a boar on the sarcophagus from Čan, efforts were also made to show a spearhead pointing into the eye of the beast. Similarly, on an Achaemenid seal discovered in Thebes, now in the British Museum, a lion being hunted from a chariot is shown on its hind legs, being blinded by an arrow which is shown already stuck in its eye.

\section{III.7. Broken lance}

A broken or abandoned spear of the victim is a relatively frequent motif, the genesis of which can be found in Mesopotamian art - the defeated enemies of Naramsin hold broken spears, which indicates their total helplessness in the face of the victorious king. Broken spears appear on the Alexander Mosaic, ${ }^{105}$ a Bithynian stele with a scene of battle with the Galatians, the remaining Pantikapaion frescoes, ${ }^{106}$ Sasanian reliefs, and also on the plaque from Orlat, and the reliefs of Naqš-e

104 Skupniewicz 2007; Skupniewicz 2018a; Skupniewicz 2018b.

105 Cohen 1997, Polański 2002: 171-192; Boardman 199: 253-257; Skupniewicz 2018a; Skupniewicz 2018b.

106 Mileczarek 1999; Goroncharovski 2006; Nefedkin 2006.
Rōstām. ${ }^{107}$ It seems that despite the temporal and spatial distance, the semantics of this sign must have remained legible, and must have referred to the inability to continue fighting, the helplessness of the warrior against the victor. Naturally, it should be noted that the long lances broke in the course of mounted combat, which gives the symbolic content an additional semblance of realism.

\section{III.8. Tree}

A tree or bushes is an element which often closes a composition or forms a caesura between scenes, unless we are dealing with a heroic rider confronted with an enemy stretched vertically. Thanks to this formal trick, the designer of the performance achieved the effect of closing the composition, even if the victim is shown kneeling or falling diagonally. The tree is a frequent element of the scenes of the rider's victory on Etruscan urns, but it also plays an important function on the sarcophagus from Čan, the stela from Čavušköy, and in later times it will become a recurring motif in the scenes of fighting with beasts in Sasanian iconography. ${ }^{108}$ Trees bounding the hunting scene also appear in walking beast-fighting scenes. Of course, a naturalistic explanation is possible for the appearance of a tree in the battle scenes, which, as an element of the landscape, sets the scene in a landscape, but attention should be paid to the selective appearance of the motif and the depiction of single trees, rather than a fragment of the forest, so a single trunk would appear as pars pro toto, i.e. schematically/symbolically by assumption.

\section{III.9. Composition - possible reconstructions}

Taking into consideration the preserved part of the relief Tang-e Sarvak III, we must exclude the possibility that originally the monument was a composition of multiple scenes, or that it could have used an elaborate model including the target of the attack in the centre of the composition. The relief could not have consisted of multiple scenes or referred to a broader formula for lack of space. The fragment of the block would not be large enough.

\footnotetext{
107 Skupniewicz 2018a; Skupniewicz 2018b.

108 Ma 2008: 243-254; Vassileva 2010: 37-46;
} Sevinč, Korpe, Tombul, Rose, Strahan, Kiesewetter, Wallrodt, 2001; Šmotlakova 2014; Woźniak 2010; Skupniewicz 2015; Skupniewicz 2018a; Skupniewicz 2018b. 
The vertical axis of Sasanian reliefs with battle scenes in most cases passes through the head of the mount of the victorious figure separating the compositions into the dominant part of the stable order on the left and the dominated side belonging to the chaos of dying on the right. The vertical axis runs quite similarly in the scenes of the victorious attack of the horseman in Achaemenid iconography, and, referring to them, depictions on bullae from Old Nysa or the terracotta plaque from Parthian Babylonia in the British Museum collection. An outstanding example of this is the scene from the sarcophagus of Čan, where the head and breast of the steed mark an almost perfect boundary between the left half clear and bright, with flat ground, and the right half with a slight slope, a thicket of tree branches and a dying infantryman. Distinguishing the scene of the victorious combat between mounted figures in the Alexander Mosaic in Pompeii, its vertical axis runs along the chest and neck of king's horse and is visually reinforced by the trunk of a tree standing behind. Also, on the Rag-i Bibi relief, the breast and head of the main figure's mount follow the vertical axis of the composition. The exceptions to this rule are the left-hand scene of the relief at Firusabad, where the heavily-armed horsemen are depicted struggling unarmed, and the scene from Naqš-e Rostam, where the two parts are relatively equivalent, making the composition almost symmetrical, although the horseman on the right has been hit by a lance while missing with his blow. In the Sasanian toreutics, which compressed the compositional models of mounted combat with beasts into a compact format because of the circular size of the plates, the vertical axis shifted towards the profile of the rider's head and body, but essentially retained the main elements of the schemes. Due to the state of damage to the Gotarzes relief at Bisutun, it is impossible to reconstruct the composition of the scenes depicted, or perhaps a composition of the kind which reminds the Hellenistic depictions consisting of several scenes, as the body line of the centrally placed horseman appears to fall on the vertical axis of the entire composition. It seems that the left and the central scene must have belonged to one of the above-mentioned compositional models, but the fleeing horse without a rider in the upper right part only resembles the scene from the vessel from Kosika and must refer to an unknown composition of the Khalchayan frieze, but the body of the defeated and the winner of the duel are missing. The Bisutun relic could certainly shed more light on the development of the composition of mounted combat images in the Parthian period, but unfortunately its state of preservation leaves it unclear
It is unlikely that Tang-e Sarvak III was distinguished by an unprecedented originality and modified a compositional principle with centuries of tradition, which remained in use also in later centuries. It should be noted that while the reality and individual iconographic elements were subject to change along with changes in the way of life, costume, military technology, the compositional assumptions showed great durability. The composition of the relief is within the historical-artistic sequence, which is testified to by the presence of individual fixed elements (a galloping rider with lance, an attendant), so it should be expected that Tang-e Sarvak III repeated one of the known formulas, with the most likely breast or neck of the mount following the central approximate dividing line of the composition. This allows us to assume that about $1 / 6$ of the length was broken off at the lower edge and about $1 / 3$ of the length at the upper edge. These are, naturally, very approximate values, which is due to the fact that the Parthian Elymais rock reliefs, or the Sasanian rock reliefs, or the late Kushan or Sasanian reliefs from Rag-e Bibi, did not have a clearly defined framework of the kind of pseudo-architectural borders of the later site at Taq-e Bostan or the earlier reliefs from Gandhara. The pictorial fields of Parthian and Sasanian rock reliefs are defined by unhewn and aligned planes, hence a certain irregularity of shape resulting in a lack of precision of proportion. This phenomenon can be clearly seen in the relief of Tang-e Sarvak III, where the surviving side edge faces slightly obliquely, so the original shape was not a perfect rectangle but a near-rectangular trapezoid.

The following images on the unpreserved part of Tang-e Sarvak III can be proposed as probable:

\section{III.9.a. Fight/confrontation with a standing infantryman (Fig. 2)}

The confrontation of a horseman with a standing infantryman, usually protected by a shield, is a formula of pre-Achaemenid origin, developed, as was illustrated above, most probably in NeoAssyrian art, adopted in Iran, known from the images of Achaemenid seal stones. With the use of lances with longer shafts, riders began to be depicted striking with lances wielded at hip height, as can be seen on the fresco from the Kinch tomb, the seal from Old Nysa or the early or pre-Kushan gem from the Rosen collection. It should be noted that since Achaemenid times this model was used to show fighting with animals stretched vertically, 


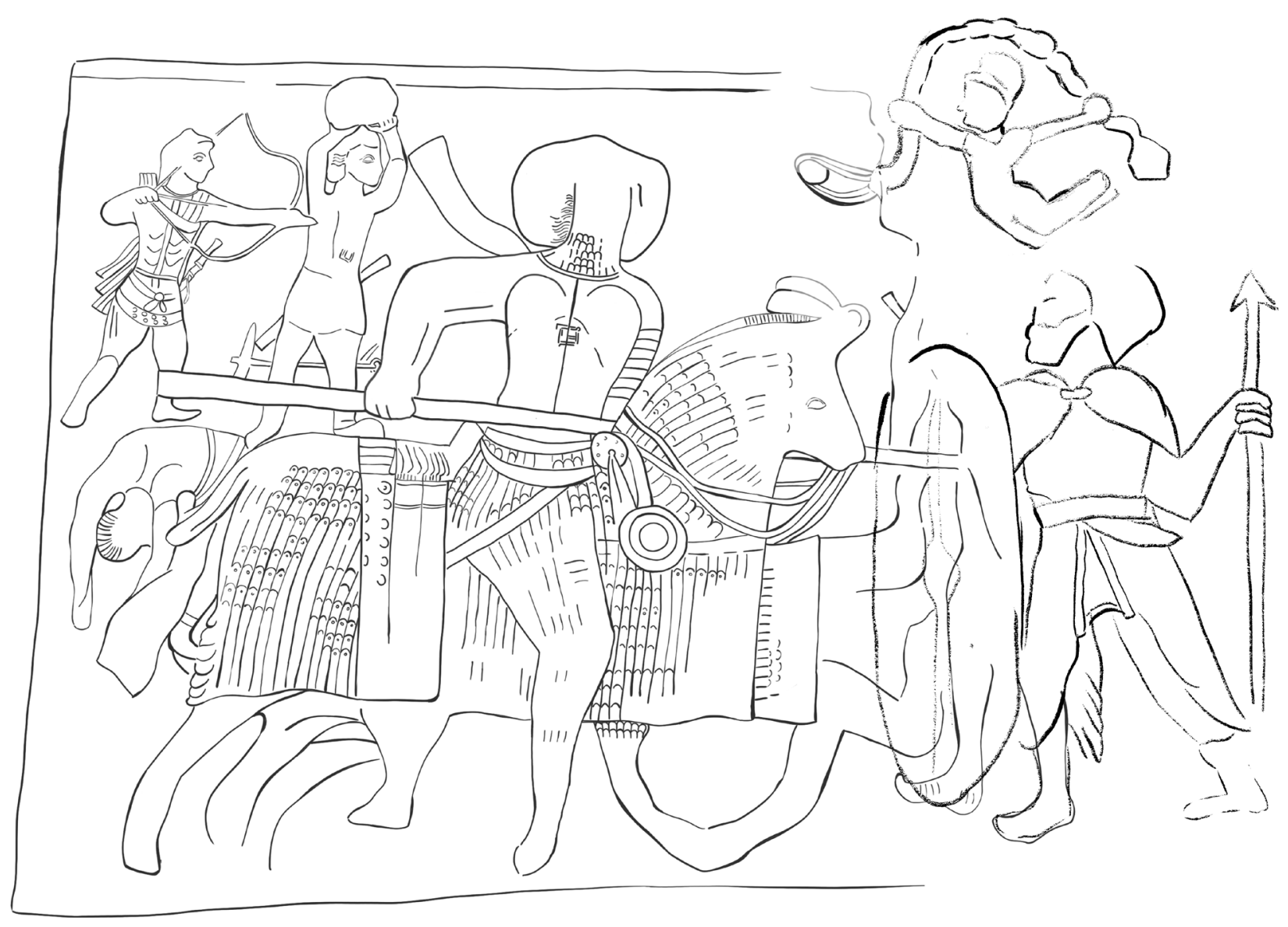

Fig. 2. Illustrative, schematic reconstruction of Tang-e Sarval III in "fight/confrontation with a standing, foot warrior" model (drawn by Eleonora Skupniewicz)

which was not in accordance with realism, but compositionally it subsumed the energy of the attack. This formula, in relation to hunting scenes, did not gain much popularity in the Parthian period, but is confirmed in a bulla from Old Nysa. In Sasanian silver, this compositional scheme became the basic formula used in depicting fighting with beasts, or 'heroic encounters', as Garrison aptly defined the genre, thus avoiding the awkward distinction between 'hunting' and 'fighting life-threatening/ forceful animals'. A standing infantryman with a shield, or protective shield-pavise, is placed perpendicular to the movement of a mounted warrior with a lance on a late, or post-Sasanian stone relief found at Taq-e Bostan. ${ }^{109}$ Admittedly, it does not directly target the rider's attack, but visually it serves as a continuation of the formula in question.

In the event that Tang-e Sarvak III were to follow the model of fighting a standing opponent on foot, the protrusions in front of the rider would have to be interpreted as the feet of the infantryman, while the arched element running under the horse's belly could be part of the body of a dead figure being rammed by a steed. The eroded shape opposite the horseman would then have to represent elements of a robe and a shield. The wavy element in the upper right part would thus be a fragment of the diadem carried by Nike and offered to the victorious cavalryman. Such an arrangement can be found on a gem from the Rosen collection, similarly the winged Nike arrives with a diadem behind the back of the main figure on the Gotarzes relief. ${ }^{110}$ Neither Nike nor a putto with diadems were placed in battle scenes on Sasanian rock reliefs. These figures are popular in scenes of parade triumphs, Nike is accompanied by mounted representations of Parthian kings placed on coins. It should be noted, however, that putti with diadems appear in scenes of "heroic encounters" with beasts on Sasanian silver, while on the "Odaenathus mosaic" from Palmyra the diadem is carried by a predatory bird to the victorious 


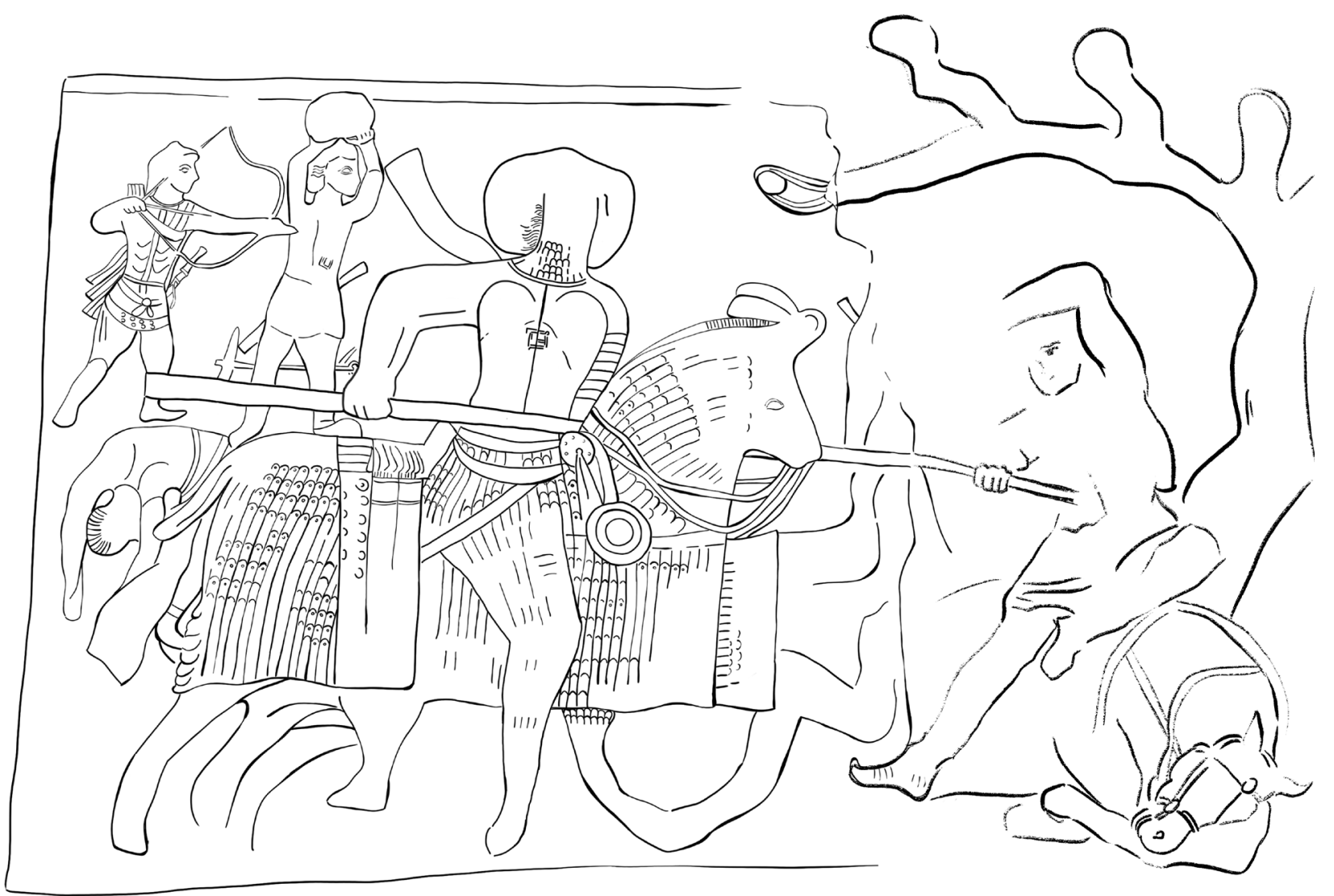

Fig. 3. Illustrative, schematic reconstruction of Tang-e Sarval III in "rider kills knocked down infantryman or horseman over slain mount. The victim shown obliquely" model (drawn by Eleonora Skupniewicz)

rider $^{111}$; what is important, on this representation, in the scene with Bellerophon killing the hydra, the predatory bird with a diadem is placed on both sides of the figure's head. The winged Nike offers some sort of object to the victorious ruler from a stone relief from Taq-e Bostan. ${ }^{12}$

This model would seem to explain most fully the obscure elements on the right side of the relief but, it should be noted, no example of the application of this formula in monumental settings is known.

III.9.b. Rider kills an overthrown infantryman or horseman over slain mount. The victim shown obliquely (Fig. 3)

The placement of the defeated opponent on a hillock, as in the case of the Čan sarcophagus, or on a slain horse stretched beneath it, as in the Alexander Mosaic and on the so-called Alexander

111 Gawlikowski 2005: 1293-1304; Harper 2006; Skupniewicz, 2015: 180-211.

112 Moradi, Compareti 2019. sarcophagus, does not change the premise of the scene's composition. In the case of Tang-e Sarvak III, the mysterious line running under the horse may be a fragment of the unbroken contour of the ground. One would also expect that the dying opponent would be shown with one leg straightened, the other sharply bent. Then the element in the upper right part could be interpreted as a fragment of a tree, which usually accompanies similar compositions, or the hind hooves of the dying horse, analogically to the relief of Gotarzes.

\section{III.9.c. "Heroic encounter" with lion (Fig. 4)}

Fighting with lions was a theme in monumental Assyrian, Achaemenid and also Parthian art. In the Sasanian period "heroic encounters" with lions became a popular theme in the decoration of silver vessels, but a representation with this theme is found on a relief from Sar-Māšhād. Scenes of mounted combat with lions are found on the gold scabbard from the Oxus treasure. Fighting with lances against lions is found on silver vessels, and on a stone relief 


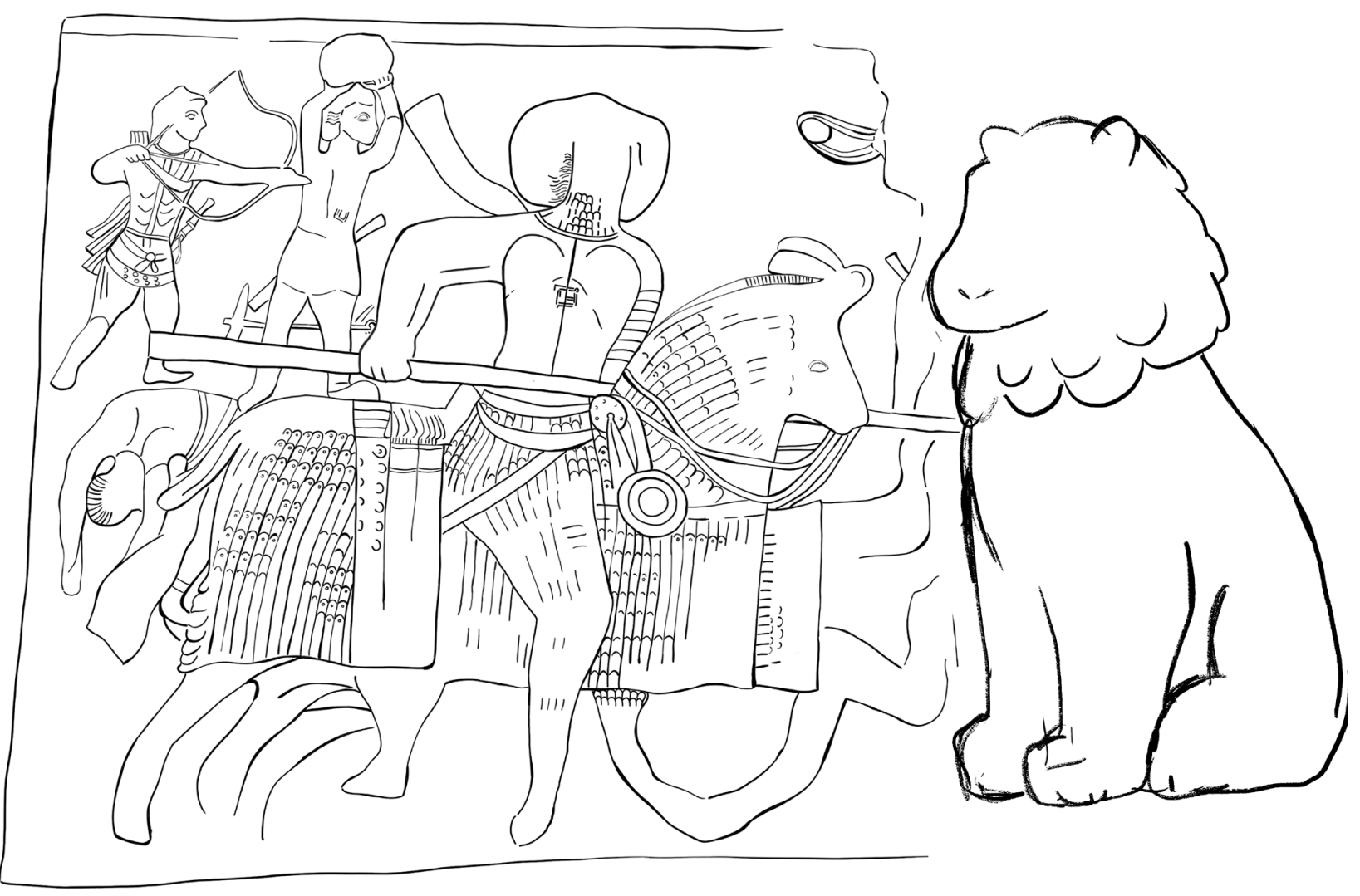

Fig. 4 Illustrative, schematic reconstruction of Tang-e Sarval III in "Heroic encounter with lion" model (drawn by Eleonora Skupniewicz)

of Hephthalite provenance. The representation closest in time is the terracotta plaque from the British Museum, where a rider in scale armour confronts a disproportionately large lion, shown as a protome. A Himyarite relief with a scene of a rider fighting a lion was found in Yemen. Assuming this possibility, the elements on the right bottom thigh would have to be interpreted as fragments of a huge paw and the mysterious bow under the horse of the attacking rider would be a lion's tail. The element on the upper right would have to be a fragment of scrub, or a diadem carried by a Nike.

\section{III.9.d. Rider combat.}

Horse rolling due to impact (Fig. 5)

One must allow for the possibility that Tang-e Sarvak III depicts a fight between horsemen. However, given the proportions of the scene, a confrontation, as in the synagogue mural from Dura Europos or Naqš-e Rōstām, should be ruled out. It should be noted, however, that in reliefs with horses violently rolling over as a result of impact, the hind hoof of the horse of the defeated enemy is at the height of the attacker's head, approximately where the elongated shape in the upper right of Tang-e Sarvak III can be seen. Then the shape running at the height of the horse's head would have to be the remains of the other leg of the overturned mount, and the shape at the bottom, under the horse's hooves would be the broken lance of the defeated person, which itself could be placed head facing either upwards or downwards.

The chronological proximity of Tang-e Sarvak III and Firusabad, where this formula occurs in a mature, fully developed form, indicates the high probability that it was known in the Late Parthian period.

\section{III.9.e. Riders combat. Fleeing horse (Fig. 6)}

The element protruding at the height of the head of the victorious rider might be interpreted as the hind leg of the fleeing horse, as is the case on Gotarzes relief, but is also present on the Kosika cup, and among the remains of the Khalchayan battle frieze. ${ }^{113}$ The position of the horse in the

113 Skupniewicz, Lichota 2017. 


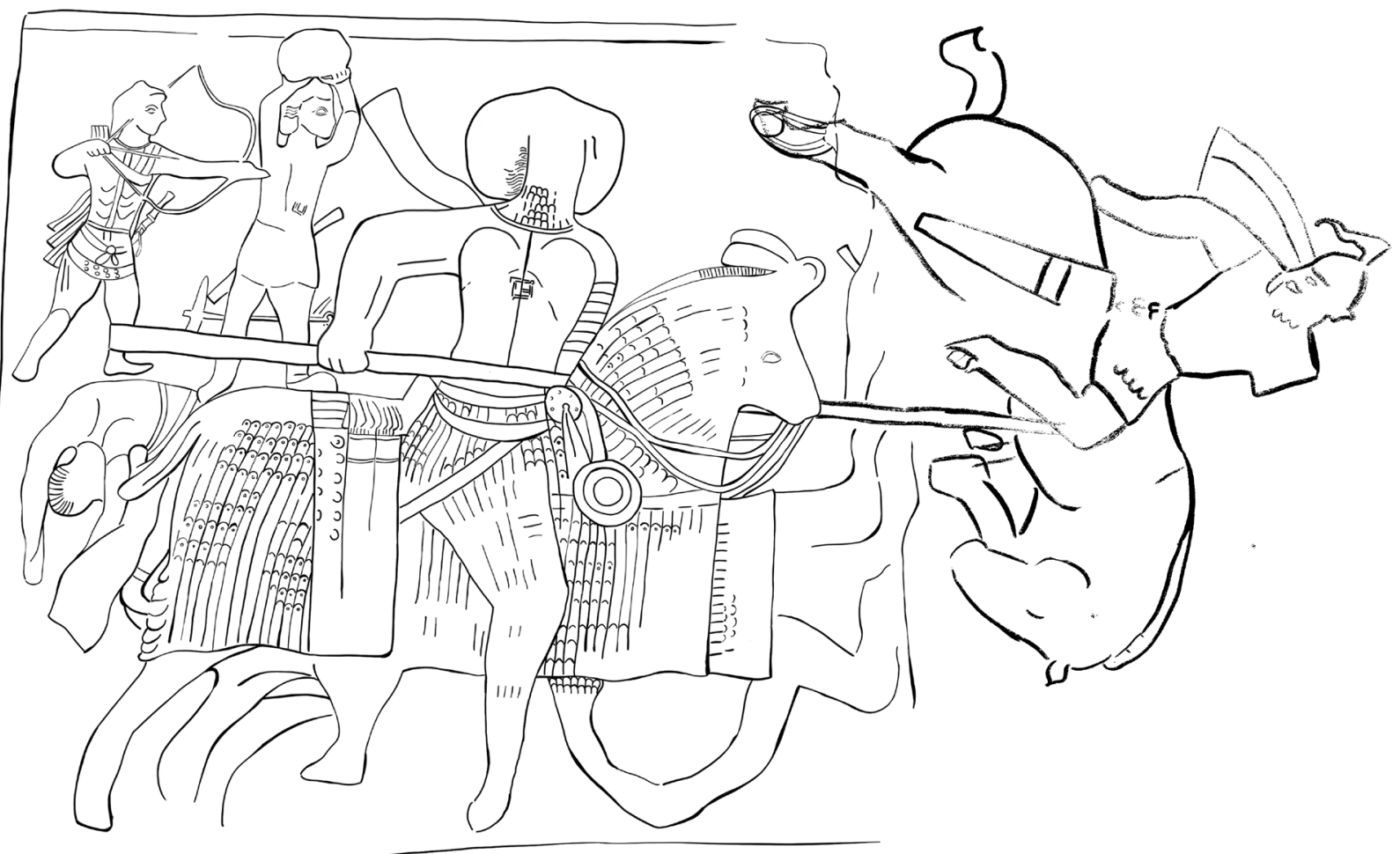

Fig. 5. Illustrative, schematic reconstruction of Tang-e Sarval III

as "Rider combat. Horse rolling due to impact" format (drawn by Eleonora Skupniewicz)

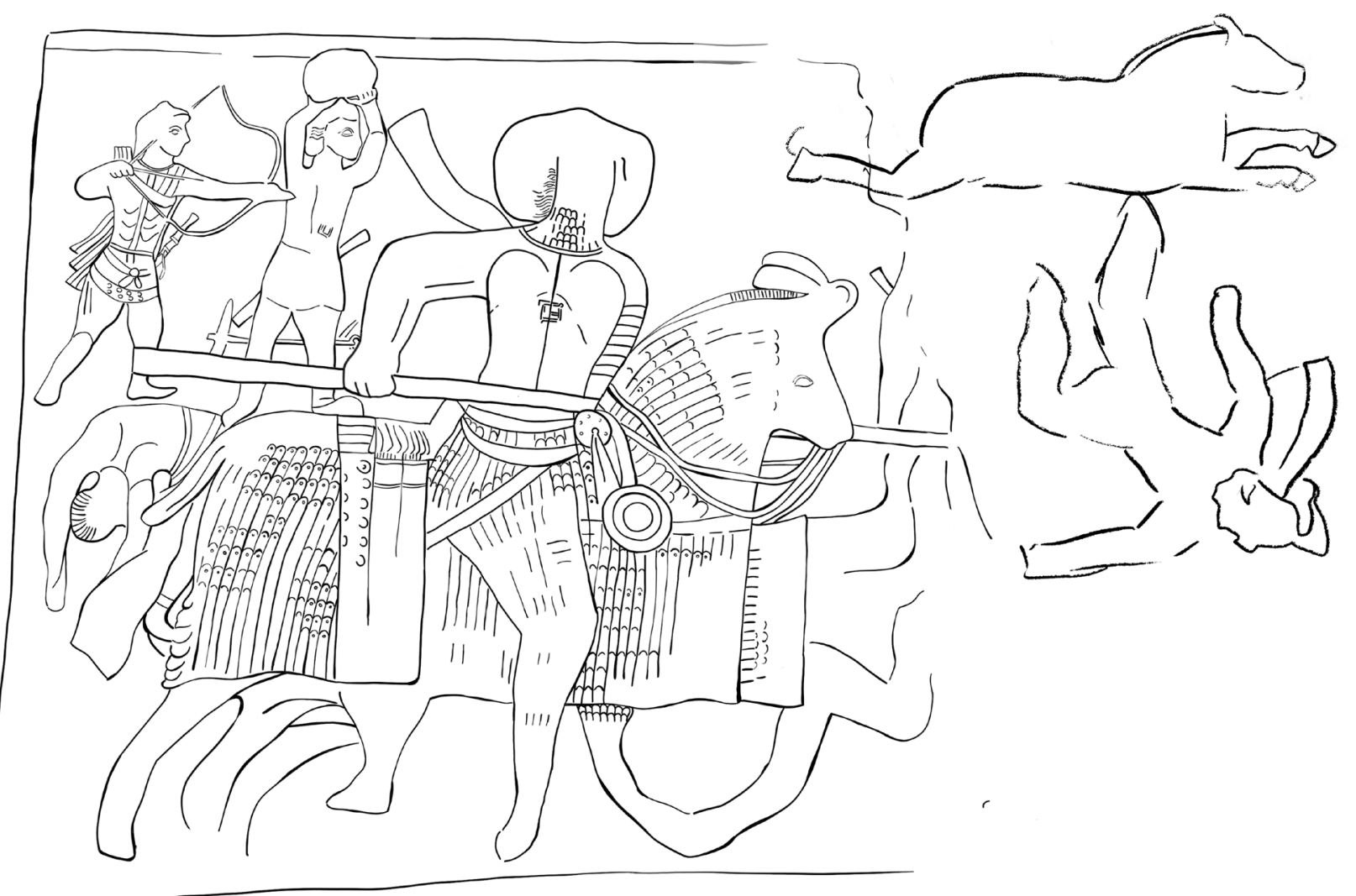

Fig. 6. Illustrative, schematic reconstruction of Tang-e Sarval III as "Riders combat. Fleeing horse" model (drawn by Eleonora Skupniewicz) 


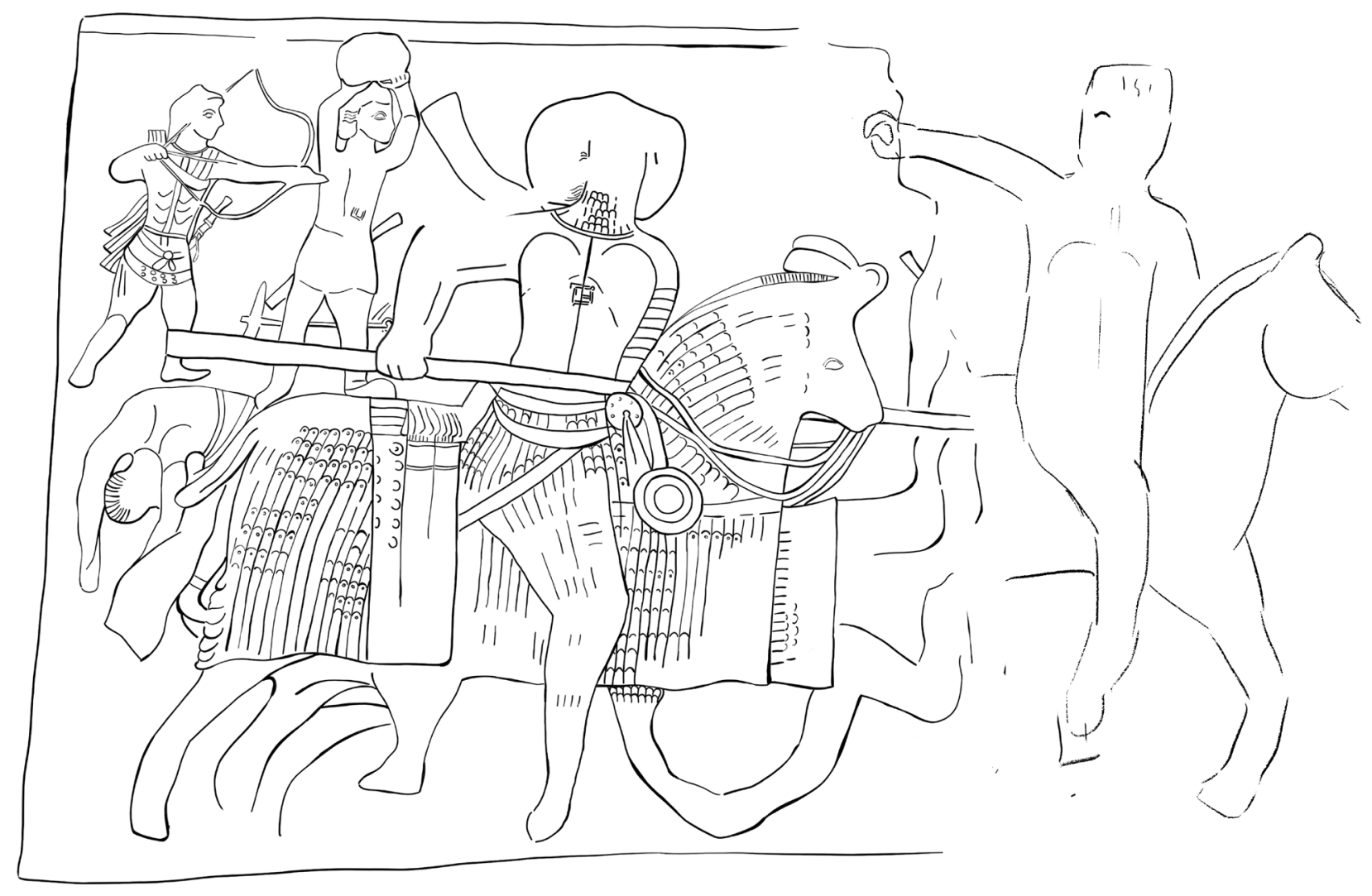

Fig. 7. Illustrative, schematic reconstruction of Tang-e Sarval III as pursuit after fleeing horseman (drawn by Eleonora Skupniewicz)

upper right corner would compositionally match the relief from Bisotun. Also, the smaller scale horse from Khalchayan must have been placed rather marginally. The important role of the riderless horse on the Kosika cup could result from an attempt to fit the monumental formula within small scale of the silver vessel.

What acts against such an interpretation is the fact that the accentuated flying gallop is a feature of Sasanian art, seemingly one of the traits differentiating monumental iconography of the new dynasty, in contrast with their Arsakid predecessors who preferred depictions of horses galloping with their hind legs on the ground.

\section{III.9.f. The pursuit of the fleeing horseman} (Fig. 7)

One must not exclude that the wavy shape at the height of the victor's head could be an arm of the fleeing enemy making a gesture of submission or pleading for mercy, with fingers touching thumb and directed towards the persecutor. Such a gesture is known from Assyrian art and is also attested in Achaemenid iconography by a golden pectoral, presently in the Miho Museum collection, and Anatolian seal stones ${ }^{114}$. This proposed reconstruction assumes the survival of the motif until late Parthian times with no surviving monuments in between. It is possible that the gesture of Darius on Alexander's Mosaic, and on an Apulian amphora repeating the topic, might derive from such model, with the very gesture being no longer legible to a Hellenistic audience. Such a speculation can be supported by the very similar gesture of extended arm with open hand made by the defeated armoured cavalrymen towards pursuing Roman troops on Trajan Column. The latter examples do not include the same specific palm arrangement, but used in a closely corresponding context clearly prove their common relationship. Such a reconstruction suffers from the lack of Iranian or Near Eastern/West Asian examples closer to the late Arsakid period, nevertheless, it cannot be excluded.

114 Benzel 1996; Bernard, Inagaki 2000; Casabone, Gabrielli 2006; Moorey 1985; Moorey 1998. 


\section{Conclusion}

The Tang-e Sarvak III relief is a valuable source of information on the armament of Iranian heavy cavalry in the Late-Arsacid period, allowing an analysis of the elements of armament in the perspective of the development of Iranian military technology of the imperial era. The armament shows the continuity of tradition in representation, despite changes in the art of war.

Similarly, an analysis of the visual structure of Tang-e Sarvak III allows the relief to be placed within the sequence of visual formulas vital to ancient Iranian art. It is the relationship with repetitive patterns that allows us to suggest possible reconstructions of the unpreserved part of the relief. The assumption is that the relief could not have gone beyond the familiar patterns of constructing battle scenes, although it may have contained depictions of material culture elements appropriate to the time and territory.

\section{Bibliography}

Abdullaev K., 1995a. Nomadism in Central Asia. The Archaeological Evidence (2nd-1st Centuries B.C.). In: Invernizzi A. (ed.) In the Land of Gryphons: Papers on Central Asian Archaeology in Antiquity, Firenze: Casa Editrica Le Lettere, 151-161.

Abdullaev K., 1995b. Armour of Ancient Bactria. In: Invernizzi A. (ed.) In the Land of Gryphons: Papers on Central Asian Archaeology in Antiquity, Firenze: Casa Editrica Le Lettere, 163-180.

Antonini S., 2005. A Himyarite Artifact in Parthian-Sasanian Style. In Scritti in onore di Giovanni M. D'Erme. Vol. 1, edited by Michele Bernardini and Natalia L. Tornesello, 1-15. Napoli: Napoli Univ. degli Studi di Napoli L'Orientale.

Barnes G. 2000. Archaeological Armor in Korea and Japan: Styles, Technology, and Social Setting, Journal of East Asian Archaeology 2, 3-4, 61-95.

Baulo A.V. 2002. Sasanidskoe serebranoe bludo s r. Synya, Arheologiya i etnografiya Evrazii, Novosibirsk, 142-148.

Behrend K.A. 2007. The Art of Gandhara in The Metropolitan Museum of Art. New York: Metropolitan Museum of Art.

Benzel K., 1996. Torque with a pectoral depicting a battle. In: O’Neil J.P. (ed.) Ancient Art from Shumei Collection, New York.
Bernard P. 1964. 'Une pièce d'armure perse sur un monument lycien' Syria 41, 195-212.

Bernard P, Inagaki H., 2000: 'Un torque achéménide avec une inscription greque au musée Miho (Japon)' Comptes rendus des séances de 1'Academie des Inscriptions et Belles-Lettres 4, 1371-1437.

Bittner S., 1985. Tracht und Bewaffung des persischen Heers zur Zeit der Achaimeniden, München.

Bivar A.D.H 1972. Cavalry equipment and tactics on the Euphrates frontier, Dumbarton Oaks Papers, 26: 273-91.

Boardman J., 1971/2001. Greek Gems and Fingerrings. Early Bronze Age to Late Classical, London.

Boardman J. 1976. 'Greek and Persian Glyptic in Anatolia and Beyond' Revue Archéologique, Nouvelle Série, Fasc. 1, Études sur les relations entre Grèce etAnatolie offertes à Pierre Demargne, $1,45-54$.

Boardman J. 2000. Persia and the West. An Archaeological Investigation of the Genesis of Achaemenid Art, London.

Bobrov Ł.A. 2013, 'Tehnika konnogo pojejnogo boja kochevnikov centralnoj AzjiXVII-serediny XIX v', Vestnik Tomskogo gosudarstvennogo universiteta. Istorija. 3(23).

Brentjes B. 1990. Zu den Reiterbildern von KurganTepe. Iranica Antiqua, vol. XXV. 173-182.

Brentjes B., 1995-6, 'Waffen der Steppenvölker (II): kompositbogen, Goryt und Pfeil - ein Waffenkomplex der Steppenvölker, AMIT 28, 179-210.

Briant P. 2020: On "Achaemenid impact" in Anatolia, In: A.P. (ed.) Dahlén Achaemenid Anatolia: Persian Presence and Impact in the Western Satrapies 546-330 BC. Proceedings of an International Symposium at the Swedish Research Institute in Istanbul, 7-8 September 2017, Boreas 37, Uppsala: Acta Universitatis Upsalensis, 9-36.

Bryant A.J. 1991. Early Samurai AD 200-1500. Oxford: Osprey Publishing.

Brzezinski R., Mielczarek M. 2002. The Sarmatians 600 BC-AD 450, Oxford: Osprey.

Casabone O. Gabrielli M., 2006, 'Brèves remarques sur un torque achéménide au musée Miho (Japon) ' Colloquium Anatolicum 5, 85-90.

Casabone O. Gabrielli M., 2007: 'A Note on Persian Armours' (w:) Delemen I. (red.) The Achaemenid Impact on Local Populations and Cultures in Anatolia, Istanbul, 265-270.

Cassin-Scott J., 1977: The Greek and Persian Wars. 500-323 BC, London. 
Cernenko R.E.V., 1983: The Scythians 700-300 BC, London.

Černenko R.E.V, 1968: Skifskiǐ dospekh, Kiev.

Chudjakov Y. 2006, Die Bewaffung der zentralasiatischen Nomaden vom 3. bis 5. Jh. n. Chr, [in:] Arms and Armour as Indicators of Cultural Transfer, M.Mode, J.Tubach (eds.), Wiesba-den, 43-78.

Ciafloni, Della Roca De Candal 2011. Sasanian Traditions in Sogdian Paintings: Hunting and Fighting Scenes, Parthica, Vol. 13, 111-128.

Cohen A., 1997: The Alexander Mosaic. Stories of Victory and Defeat, Cambridge.

Compareti M. 2006, Iconographical Notes on Some Recent Studies on Sasanian Religious Art, Annali di Ca' Foscari, XLV, 3, 163-200.

Compareti M. 2018, The Late Sasanian Figurative Capitals at Taq-i Bustan: Proposal Regading Identification and Origins. In: Y. Kadoi (ed.), Persian Art. Image-Making in Eurasia, Edinburgh: Edinburgh University Press, 20-36.

Connolly P. 2000, Experiments with the sarissa - the Macedonian pike an dcavalry lance - a functional view. Journal of Roman Military Equipment Studies 11. 103-112.

Coulston J.C. 1986. Roman, Parthian and Sassanid Tactical Developments, [in:] The De-fence of the Roman and Byzantine East, A.R. Hands, D. Phil, D.R. Walker (eds.), BAR series, Oxford, 59-75.

Dedjulkin A.V. 2021, Evolucija zheleznogo dospeha $\mathrm{v}$ ellinisticheskom mire. Istoricheskoe oruzhie v muzejnyh i chastnyh sobranijah. Vyp. 2 Mozskva. 14-39.

Dien A.E. 1981. A Study of Early Chinese Armor, Artibus Asia XLIII, 1/2, 5-66.

Dien A.E. 2000a. A Brief Survey of Defensive Armor Across Asia, Journal of East Asian Archaeology 2, 3-4, 1-22.

Dien A.E. 2000b. Armor in China Before the Tang Dynasty, Journal of East Asian Archaeology 2, 3-4, 23-59.

Downey S,B. 2006. Arms and Armour as Social Coding in Palmyra, the Palmyrene, and Dura Europos. In: Mode M., Tubach J. (eds.) Arms and Armour as Indicators of Cultural Transfer. The Steppes and Ancient World from Hellenistic Times to the Early Middle Ages. Wiesbaden: Dr. Ludwig Reichelt Verlag. 321-355.

Eadie J.W. 1967, The Development of Roman Mailed Cavalry, „The Journal of Roman Studies", 57, 161-173.

Gaibov V.A., Košelenko G.A. 2008. A Horseman charging a Foot Soldier: A New Subject in Parthian Glyptic Art, Parthica 10, pp. 99-107.
Gaibov V.A., Košelenko G.A. 2013. Ot Horezma do Bospora: o „sarmackoj"posadke vsadnikov. Problemy isyorii, filologii, kultury 2 (40). 286296.

Gamber von O., 1964, 'Dakische und Sarmatische Waffen auf den Reliefs der Traianssäule 'Jahrbuch der Kunshistorischen sammlungen in wien 60 (XXIV), 7-34.

Garrison M.B. 2010, The Heroic Encounter in the Visual Arts of Ancient Iraq and Iran ca. 1000500 BC, Counts D.B., Arnold B. (eds.) The Master of Animals in Old World Iconography, Budapest 2010, 151-174.

Gorelik M.V., 1971: 'Opyt rekonstrukcīi skifskih dospehov po pamyatniku skifskogo izobrazitelnogo iskusstva - zolotōi plastinke iz geremesova kurgana' Sovetskaya Arheologya 3, 236-245.

Gorelik M.V., 1982: 'Zaščitnoe vooruženie persov i mid'an ahemenidskogo vremeni' Vestnik Drevneī Istorii 3(161), 90-106.

Gorelik M.V., 1982b: 'Kushanskī̄ dospeh' in Drevnaya Indya, Moskva, 82-112.

Gorelik M.V., 1987: 'Sakskiī dospeh' in Centralnaya Aziya. Novye pamyatniki pismennosti $\mathrm{i}$ iskusstva, Moskva 110-133, 357-373.

Gorelik M.V., 1993: 'Zashchitnoe vooruženie stepnoī zony evrazii i primykaīuščih $\mathrm{k}$ neī territorī̄ v I tys n.é', in J. Hudyakov (ed.) Voennoe delo naselenī̄a yuga Sibirii i Dalnego Vostoka, Novosibirsk, 149-179.

Gorelik M.V. 2003, Oruzhije drevnego Vostoka. Moskva.

Goroncharovski V.A. 2006, Some Notes on Defensive Armament of the Bosporan Cavalry in the First Centuries AD, [in:] Arms and Armour as Indicators of Cultural Transfer, M.Mode, J.Tubach (ed.), Wiesbaden, 445-452.

Goroncharovskiy V.A., Nikonorov V.P. 1987. Iluratskiy katafraktariy. $\mathrm{K}$ istoriy antichnoy tyazheloy kavaleriy, Vestnik Drevniey Istorii 1(180). 201-213.

Haerinck H. 2005. Tang-e Sarvak, https://www.iranicaonline.org/articles/tang-e-sarvak-1\#prettyPhoto accessed 14/02/2021.

Harper P.O. 2006. In Search of a Cultural Identity. Monuments and Artifacts of the Sasanian Near East. 3rd to 7th Century A. D., New York: Bibliotheca Persica, 10-11.

Head D. 1992. The Achaemenid Persian Army, Stockport.

Ilyasov J. 2003. Covered Tail and „Flying” Tassels, „Iranica Antiqua”, 259-325.

Ilyasov J. Ya. 2013. Ob zobrazhenii na rogovom predmete s gorodishcha Kalaly-Gyr 2. Rossijskaja Arheologija 2013/2, 96-104. 
Ilyasov J.Ya., Rusanov D.V. 1997/98. A Study on the Bone Plates from Orlat. Silk Road Art and Archaeology 5. 107-159.

James S. 2004. Excavations at Dura-Europos 19281937. Final Report VII. The Arms and Armour and other Military Equipment, London.

Jäger U. 2006. Der griechisch-hellenistische Muskelpanzer und sein Fortleben in Zentralasien, 4. Jh. v. Chr. Bis 8./9. Jh. N. Chr.: Ein kurzer Betrag zum rustungstechnologischen Nachlebens des Hellenismus in Zentralasien, In: Mode M., Tubach J. (eds.) Arms and Armour as Indicators of Cultural Transfer. The Steppes and Ancient World from Hellenistic Times to the Early Middle Ages. Wiesbaden: Dr. Ludwig Reichelt Verlag. 19-42.

Kawami T.S. 1987. Monumental Art of the Parthian Period in Iran, Acta Iranica 26, Leiden: E.J. Brill.

Kawami T.S. 2013. Parthian and Elymaean rock reliefs. In: P.T. Potts (ed.) The Oxford Handbook of Ancient Iran. Oxford: Oxford University Press: 751-765.

Khorasani M. M. 2010. Lexicon of arms and armor from Iran a study of symbols and termi-nology. Tübingen: Legat.

Litvinkiī B.A., Pyankov I.V., 1966: 'Voennoe delo u narodov srednē̄ azīi v VI-IV vv do n.e Vestnik Drevnēi Istorii 3(97), 36-52.

Luschey H. 1990. Bisotun, ii, Archaeology https:// iranicaonline.org/articles/bisotun-ii\#pretty Photo.

Ma J., 2008. Mysians on the Çan Sarcophagus? Ethnicity and Domination in Achaemenid Military Art, Historia: Zeitschrift für Alte Geschichte 57/ 3, 243-254.

Mambetullaev M., 1977: 'Relefnoe izobraženie vsadnika na keramicheskōi flage iz Humbuz Tepe' Sovetskaya Arheologiya 3, 278-281.

Malandra W. W. 1973. "A glossary of terms for weapons and armor in old Iranian." Indo-Iranian Journal 15.4: 264-89.

Markle M.M.III 1977, The Macedonian Sarissa, Spear, and Related Armor, American Journal of Archaeology 81/3, 323-339.

Markle M.M.III 1978, Use of the Sarissa by Philip and Alexander of Macedon, American Journal of Archaeology 82/4, 483-497.

Mathiesen H.E. 1992. Sculpture in the Parthian Empire. A Study in Chronology, vol. 1-2, Aarhus: Aarhus University Press.

Meljukova A.I. 1964. Vooruzhenie Skifov. Moskva

Michalak M. 1987, The Origins and Development of Sasanian Heavy Cavalry, „Folia Orientalia”, $24,73-205$.
Mielczarek M. 1993. Cataphracti and Clibanarii. Studies on the Heavy Armoured Cavalry of the Ancient World, Łódź: Wydawnictwo Uniwersytetu Łódzkiego.

Mielczarek M. 1998, Cataphracts - a Parthian element In the Seleucid Art of war, „Electrum”, 2, 101-106.

Moorey P.R.S., 1985: 'The Iranian Contribution to Achaemenid Material Culture' Iran. Journal of the British Institute of Persian Studies XXIII, 21-38.

Moorey P.R.S., 1998: 'Material Aspects of Achaemenid Polychrome Decoration and Jewellery" Iranica Antiqua XXXIII, 155-171.

Moradi Y., Compareti M. 2019. A Sasanian figured relief plaque from Taq-e Bostan, Parthica 21, 179-188.

Nefedkin A.K. 2006. Sarmatian Armour According to Narrative and Archaeological Data. In: Mode M., Tubach J. (eds.) Arms and Armour as Indicators of Cultural Transfer. The Steppes and Ancient World from Hellenistic Times to the Early Middle Ages. Wiesbaden: Dr. Ludwig Reichelt Verlag. 434-444.

Negin A., d'Amato R. 2018. Roman Heavy Cavalry (1). Cataphractarii and Clibanarii, 1st Century BC-5th Century AD. Oxford: Osprey Publishing.

Negin A., Kamisheva E.M. 2018. Armour of a Cataphractarius from the Roshova Dragana Barrow. Archaeologia Bulgarica XXII, 1, 45-70.

Nicolle D. 1991, Rome's Enemies (5). The Desert Frontier, Oxford: Osprey.

Nicolle D. 1996, Sasanian Armies. The Iranian Empire early 3 rd to mid-7th centuries AD, Stockport: Montvert.

Nicolle D. 1998, Medieval Warfare Source Book. Christian Europe and its Neighbours, London.

Nicolle D. 2017, Horse Armour in the Medieval Islamic Middle East, Arabian Humanities 8: Le cheval dans la péninsule Arabique, 1-60.

Nikonorov V.P. 1992. Greko-baktriyskaya tyazhelaya kavaleriya ( $\mathrm{k}$ istorii voennogo dela na ellenistchesom srednem vostoke). In: Mezhdunarodnaya konferentsiya Srednyaya Aiya i mirovaya civilizactsya, Tashkent, 104-107

Nikonorov V. P. 1997. Armies of Bactria, vol 1-2, Stockport: Montvert.

Nikonorov V.P. 2005. K voprosu o parfiyanskom nasledii v sasanidskom Irane: voennoe delo. In: Nikonoro V.P. (ed.) Tsentralnaya Aziya ot Ahemenidov do Timuridov. Arheologiya, isoriya, kultura. St. Petersburg: Institut istorii materiyalnoy kultury RAN. 142-179.

Nikonorov V. P. 2009. More about western elements in the armament of Hellenistic Bactria: the case 
of the warrior terracotta from Kampyr-Tepe, Archäologie in Iran und Turan, Band 19. 187204.

Nikonorov V.P. 2014, Boevye topory i ih kult drevnih narodov Centralnoj Azji i Irana (ot rannogo zheleznogo veka do rannogo serednevekovja, (w:) Arheologija drevnih obshschestv evrazji: hronologija, kulturogenez, religjoznye vozzrenija.

Nikonorov V.P. 2015, Kult boevyh toporov u drevnih iranojazichnyh narodov: skify Severnogo Prichernomorja (w:) Nikonorow V.P., Alyokshin A., Akademicheskoe voskokovedenie v Rosii i stranah blizhnego zarubezha (2007-2015). Arheologija, istorija, kultura,St. Petersburg

Nikonorov V.P. 2020. Sasanidskiye boevye reliefy i proishozhdeniye temu konnvoy dueli na pikah $\mathrm{v}$ proklamativnom iskusstve doislamskogo Irana, Arheologicheskie Vesti 29, 215-238.

Nikonorov V.P., Hudyakov Yu. S. 1999. Izobrazheniya voinov iz orlatzkogo mogilnika, In: O.A. Mytko (ed.), Evraziya. Kulturnoe nasledye drevnih civilizatsiy, Novosibirsk: Novosibirskiy Gosudarstvennyi Universitet, 141-156.

Nikonorov V. P., Savchuk A. 1992. New Data on Ancient Bactrian Body-Armour (In the Light of Finds from Kampyr Tepe), Iran XXX, 49-54.

Olbrych M.J. 1999. Seleucydzi i Kultura Ich Epoki. In: Wolski J. Dzieje i Upadek Imperium Seleucydów. Kraków: Enigma Press. 136-208.

Olbrycht M. 2001. "The Origins of the Arsacid Parthian Cavalry: Some Remarks." In The Role of Ahalteke Horse in the Formation of World Horse-Breeding: Materials for the Inter-national Conference, edited by Vadim Mikhailovich Masson, 108-11. Ashgabat: The State Institute of Cultural Heritage of the Peoples of Turkmenistan.

Olbrycht M.J., 2004: 'Aleksander Wielki i świat irański', Rzeszów 2004.

Olbrycht M.J., 2010: 'Central Asian, Achaemenid and Parthian Cavalry Developments' Drevnyeye kultury evrazīi. Materyali meždunarodnoī konferencīi posvyashchonoy 100-letiyu so dnya roždyeniya A.N. Bernshtama St. Petersburg 2010, 196-200.

Olbrycht M.J., 2010: 'K voprosu o proishoždenii konnicy katafraktov v Irane i Sredneī Azīi‘ in Erofeeva I.V., Žanaev B.T., Masanova L.E. (eds.) Rol nomadov evaziīskih stepeī v razvitii mirovogo voennogo isskusstva, Almaty, 66-85.

Olbrycht M.J., 2013: 'Konnica wielkiego króla. Uwagi na temat taktyki jazdy irańskiej w epoce Achemenidów ' in R. Kulesza, M. Stępien, E. Szabat, M. Daszuta (eds.) Świat starożytny. Państwo i społeczeństwo, Warszawa, 50-59.
Pilipko V.N. Arms and Armour from Old Nisa, In: Mode M., Tubach J. (eds.) Arms and Armour as Indicators of Cultural Transfer. The Steppes and Ancient World from Hellenistic Times to the Early Middle Ages. Wiesbaden: Dr. Ludwig Reichelt Verlag. 259-294.

Pirson F. 2014. Ansichten des Krieges. Kampfreliefs klassischer und hellenistischer Zeit im Kulturvergleich, Wiesbaden: Dr Ludwig Reichert.

Polański T., 2002: Ancient Greek Orientalist Painters. The Literary Evidence, Kraków.

Potts D.T. 2007. "Cataphractus and kamāndār: Some Thoughts on the Dynamic Evolution of Heavy Cavalry and Mounted Archers in Iran and Central Asia." Bulletin of the Asia Institute, 21: 149-58.

Pugachenkova G.A. 1966. O pantsirnom vooruženi parfyanskogo i baktriyskogo voinstva. Vestnik Drevney Istorii 2, 27-43.

Pugachenkova G.A. 1987. Obraz Kangyuytsa v sogdiyskocm iskusstve Iiz otkrytiy Uzbekistanskoy iskusstvovedecheskoy ekspeditsii). In: Pugachenkova G.A. (ed.) Iz hudozhestvennoy sokrovishchitsy Srednego Vostoka, Tashkent: Iztatelstvo Literatury i Iskusstva. Accessed online: http://kronk.spb.ru/library/ pugachenkova-ga-1987-5.htm (14/02/2021).

Reade J.E. 2018. The Assyrian Royal Hunt. In: Brerenton G. (ed.), The BP exhibition. Iam Ashurbanipal king of the world, king of Assyria. London: Thames and Hudson, 52-79.

Ritter N.C. 2010. Die altorientalischen Traditionen der sasanidischen Glyptik. Form-GebrauchIkonographie, Wien: LIT, Berlin.

Robinson H.R.R., 1967: Oriental Armour, New York.

Sekunda N. 1988. "Achaemenid Military Terminology.” AMI, 21: 69-77.

Sekunda, N.V., 1992: The Persian Army 560-330 $\mathrm{BC}$, Oxford.

Sekunda N 1994. The Seleucid Army. Stockport: Montvertmy (p. 76).

Sekunda N.V., 2001, The Sarissa, Acta Universitatis Lodzensis 23, 13-41.

Sekunda, N.V., 2002: Marathon 490 BC. The first Persian invasion of Greece, Oxford.

Sekunda N.V, 2012. Macedonian Armies after Alexander 323-168 B.C. Oxford: Osprey.

Sekunda N.V. 2013. The Antigonid Army, Gdańsk: Akanthina.

Sevinč, N., Korpe, R., Tombul, M., Rose, C.B., Strahan, D., Kiesewetter, H., Wallrodt, J. 2001. New Painted Graeco-Persian Sarcophagus from Qan. Studia Troica 11, pp. 383-420. 
Shenkar M. 2014. Intangible Spirits and Graven Images: The Iconography of Deities in the Pre-Islamic Iranian World, Leiden: Brill.

Skupniewicz P.N. 2007b, Sasanian Plate Armour. Fasciculi Archaeologiae Historicae XIX, 1933.

Skupniewicz P.N. 2009. Shafted Weapons of Sasanian Hunting Iconography, Fasciculi Archaeologiae Historicae Vol. XXII, 49-64.

Skupniewicz P.N. 2014, Sasanian Horse Armor, Historia i Świat 3, 35-59.

Skupniewicz P.N. 2015, The Iconographic Function of Armor in Sasanian Art. Rivista deli Studi Orientali LXXXVIII, 235-265.

Skupniewicz P.N. 2015. Tabriz Museum Battle Dish. Formal Considerations, Metamorfozy Istorii 6, Pskov, 180-211.

Skupniewicz P.N. 2018A. Mozaika Aleksandra Wielkiego i hellenistyczne ikony przemocy, Istorija Religiy Ukrainy Vol 28, 3-16.

Skupniewicz P.N. 2018B. Hellenistyczne estetyczne modele ujmowania walki konnej a Mozaika Aleksandra w kontekście eschatologicznym. Studium formalne. In: Minta-Tworzowska D. (ed.), Estetyka w archeologii. Obrazowanie w pradziejach i starożytności, Gdańsk: Polska Akademia Nauk, Muzeum Archeologiczne w Gdańsku, 317-342.

Skupniewicz P., Maksymiuk K. 2019. Gordāfarid, Penthesilea and Athena: the identification of a Greek motif in Ferdowsī’s Šāh-nāma and its possible association with Hellenistic art in the East, Mediterranean Historical Review, 34:2, 123-143.

Skupniewicz P. 2021, Mounted Combat Scenes on the Bronze Plaque from Sana'a, Amazonomachia in Yemen, Persica Antiqua, 69-85.

Skupniewicz P.N., Lichota M. 2017, Diadem on the head from Khalchayan battle scene and possible reconstruction of the composition, (in:) Maksymiuk K., Karamian G. (eds.) Crowns, hats, turbans and helmets. The headgear in Iranian history. Vol. 1. Pre-Islamic Period, Siedlce, 69-95.

Stornach D., 1998: 'On the Date of the Oxus Gold Scabbard and Other Achaemenid Matters' Bulletin of the Asia Institute, New Series, Vol. 12, 231-248.

Stornach D., 1998: 'Riding in Achaemenid Iran: New Perspectives' Eretz-Israel: Archaeo-logical, Historical and Geographical Studies, 216237.

Šmotlakova K., 2014: 'Iconographical Themes on Funerary Monuments in Achaemenid Ana-tolia' in Hrnčiarik (ed.) Turkey through the Eyes of Classical Archaeologists. 10th Anniver-sary of cooperation between Trnava University and Turkish Universities, Trnava, 38-49.

Tafażżolī A.. 1993-1994. "The List of Terms for Weapons and Armour in Western Middle Iranian." Silk Road Art and Archaeology, 3: 187-98.

Tarn W.W. 1984. Hellenistic Military And Naval Developments, Chicago.

Thompson E. 2008. Composition and Continuity in Sasanian Rock Reliefs, Iranica Antiqua Vol. 43, 300-358.

Tuplin C. 2020. 'Sigillography and Soldiers: Cataloguing Military Activity on Achaemenid Period Seals' in: E.Dusinberre \& M.Garrison (eds.), The Art of Empire in Achaemenid Persia. Festschrift in honor of Margaret Cool Root, Leiden.

Vanden Berghe L., Schipman K. 1985. Les Reliefs Rupestre des Elymaide (Iran) de l'Epoque Parthe. Gent: Iranica Antiqua.

von Gall H. 1990b. Das Reiterkampfbild in der iranischen und iranisch beeinflußten Kunst parthischer und sasanidischer Zeit, Berlin: Gebe. Mann Verlag.

William Jackson A. V. 1894. "Herodotus VII.61: The Arms of the Ancient Persians Illustrat-ed from Iranian Sources." In Classical Studies in honour of H. Drisler, 95-125. New York: Macmillan \& Co.

Wilcox P. 1986, Rome's Enemies (3). Parthians \& Sassanid Persians, Oxford.

Woźniak M.A., 2010: Armie starożytnej Persji. Od powstania państwa Achemenidów do upadku imperium sasanidzkiego, ZabrzeWójcikowski R.S. 2010. Konnica irańska w okresie późnoachemenidzkim, [in:] Hortus Historiae, Dąbrowa E., Dzielska M., Sprawski S. (eds.), Kraków, 123-134.

Wójcikowski, R. 2013. "The graffito from Dura-Europos: Hybrid armor in Parthian-Sasanian Iran." Anabasis, 4: 233-48.

Wójcikowski R.S. 2014. Kawaleria Perska. W Okresie Wczesnosasanidzkim. Aspekty Społeczne i Militarne. Tom I. Konnica w Iranie przed Sasanidami. Kampanie Sasanidzkie, Oświęcim: Napoleon $\mathrm{V}$

Yule P., Robin. C.J. 2007. Himyarite Knights, Infantrymen and Hunters. Arabia, 3: 261-71.

Patryk N. Skupniewicz ORCID 0000-0002-8119-5449

University of Natural Sciences and Humanities in Siedlce, Poland Institute of History varaz777@yahoo.com 